\title{
Monthly-averaged anthropogenic aerosol direct radiative forcing over the Mediterranean based on AERONET aerosol properties
}

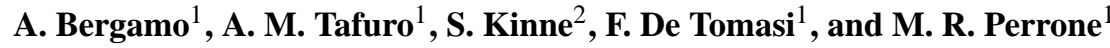 \\ ${ }^{1}$ CNISM, Physics Department, University of Salento, Italy \\ ${ }^{2}$ Max Planck Institute für Meteorologie, Hamburg, Germany
}

Received: 7 April 2008 - Published in Atmos. Chem. Phys. Discuss.: 7 July 2008

Revised: 7 October 2008 - Accepted: 7 October 2008 - Published: 4 December 2008

\begin{abstract}
The all-sky direct radiative effect by anthropogenic aerosol $\left(\mathrm{DRE}_{\mathrm{a}}\right)$ is calculated in the solar $(0.3-4 \mu \mathrm{m})$ and infrared $(4-200 \mu \mathrm{m})$ spectral ranges for six Mediterranean sites. The sites are differently affected by pollution and together reflect typical aerosol impacts that are expected over land and coastal sites of the central Mediterranean basin. Central to the simulations are aerosol optical properties from AERONET sun-/sky-photometer statistics for the year 2003. A discussion on the variability of the overall (natural + anthropogenic) aerosol properties with site location is provided. Supplementary data include MODIS satellite sensor based solar surface albedos, ISCCP products for high- mid- and low cloud cover and estimates for the anthropogenic aerosol fraction from global aerosol models. Since anthropogenic aerosol particles are considered to be smaller than $1 \mu \mathrm{m}$ in size, mainly the solar radiation transfer is affected with impacts only during sun-light hours. At all sites the (daily average) solar $\mathrm{DRE}_{\mathrm{a}}$ is negative all year round at the top of the atmosphere (ToA). Hence, anthropogenic particles produce over coastal and land sites of the central Mediterranean a significant cooling effect. Monthly $\mathrm{DRE}_{\mathrm{a}}$ values vary from site to site and are seasonally dependent as a consequence of the seasonal dependence of available sun-light and microphysical aerosol properties. At the ToA the monthly average $\mathrm{DRE}_{\mathrm{a}}$ is $-(4 \pm 1) \mathrm{W} \mathrm{m}^{-2}$ during spring-summer (SS, AprilSeptember) and $-(2 \pm 1) \mathrm{W} \mathrm{m}^{-2}$ during autumn-winter (AW, October-March) at the polluted sites. In contrast, it varies between $-(3 \pm 1) \mathrm{W} \mathrm{m}^{-2}$ and $-(1 \pm 1) \mathrm{W} \mathrm{m}^{-2}$ on SS and AW, respectively at the less polluted site. Due to atmospheric absorption the $\mathrm{DRE}_{\mathrm{a}}$ at the surface is larger than at the ToA. At the surface the monthly average $\mathrm{DRE}_{\mathrm{a}}$ varies between the most and the least polluted site between $-(7 \pm 1) \mathrm{W} \mathrm{m}^{-2}$ and $-(4 \pm 1) \mathrm{W} \mathrm{m}^{-2}$ during SS, and between $-(4 \pm 3) \mathrm{W} \mathrm{m}^{-2}$
\end{abstract}

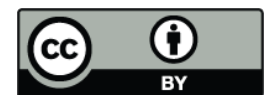

Correspondence to: M. R. Perrone (perrone@1e.infn.it) and $-(1 \pm 1) \mathrm{W} \mathrm{m}^{-2}$ during AW. The $\mathrm{DRE}_{\mathrm{a}}$ at infrared wavelengths is positive but negligible, especially at the ToA $\left(<0.3 \mathrm{~W} \mathrm{~m}^{-2}\right)$. The average of $\mathrm{DRE}_{\mathrm{a}}$ monthly-means referring to all sites has allowed getting a ToA- and sfc-DRE yearly-mean value of $-(3 \pm 2)$ and $-(5 \pm 3) \mathrm{W} \mathrm{m}^{-2}$, respectively at solar wavelengths. Last data, even if refer to a particular year, indicate that the radiative energy-balance of Central Mediterranean land and coastal sites is quite affected by anthropogenic particles.

\section{Introduction}

It is well known that aerosol particles, both of natural and anthropogenic origin, affect the climate of the EarthAtmosphere-System directly by scattering and absorbing solar radiation and indirectly by modifying cloud microphysical properties. Nevertheless, the level of scientific understanding of the direct and indirect forcing by aerosols is classified as "med-low" and "low", respectively by the Intergovernmental Panel on Climate Change (IPCC, 2007), as a consequence of the variable nature of aerosols on regional and seasonal scales. Multiple-technique measurements are currently used to assess the aerosol impact on global climate. Long-term continuous observations from satellites, networks of ground-based instruments and dedicated fieldmeasurements in clean and polluted environments are currently used to feed global aerosol and climate models (e.g. Kaufman et al., 2002).

The Moderate Resolution Imaging Spectro-radiometer (MODIS) has been launched onboard the EOS Terra and Aqua polar-orbiting satellites since December 1999 and May 2002, respectively, for multi-disciplinary studies of landatmosphere and ocean-atmosphere interactions (e.g. King et al., 1992). The Aerosol Robotic Network (AERONET) has also been established to provide aerosol optical depth retrievals and to get additional details on aerosol column

Published by Copernicus Publications on behalf of the European Geosciences Union. 
averaged properties. AERONET is a federated network of about 400 automatic sun/sky radiometers worldwide, coordinated by the NASA Goddard Space Flight Center (Holben et al., 1998). These (global) data on aerosols have led to new attempts to quantify accurately the global aerosol impact on the radiative energy balance of the Earth-Atmosphere system (e.g. Chung et al., 2005; Yu et al., 2006). The assessment of the direct radiative effect (DRE) by anthropogenic aerosols is of great interest. Estimates of the direct climate forcing (anthropogenic aerosols) so far have been predominantly model-based (e.g. Giorgi and Bi, 2002). Nine different global models with complex component aerosol modules have recently been employed by Schulz et al. (2006) to produce independent estimates of the DRE due to anthropogenic aerosols and hence, to provide a new global annual estimate $\left(-0.22 \pm 0.16 \mathrm{~W} \mathrm{~m}^{-2}\right)$ of the anthropogenic aerosol DRE at the top of the atmosphere.

A detailed analysis on the current observation-based methods to determine the anthropogenic aerosol contribution to the observed aerosol optical depth (AOD) is provided in the paper by Yu et al. (2006). Kaufman et al. (2005) show that the fraction of the aerosol originating from anthropogenic activity can be estimated from MODIS measurements with an uncertainty of $\pm 30 \%$ over the oceans. The so-derived average anthropogenic AOD is about 0.033 , consistent with assessments of 0.03-0.36 from global chemical transport models: GOCART, LMDZ-LOA, and SPRINTARS (Schulz et al., 2006).

The present study focuses on the anthropogenic aerosol DRE over the Mediterranean. The Mediterranean basin has a particular relevance in this kind of studies as this area is particularly affected by air pollution. In addition to seaspray aerosols and mineral dust particles from North Africa, long-range transported urban/industrial and biomass burning aerosols from Northern and Eastern Europe regions converge in the Mediterranean. As a consequence, several studies indicate that the aerosol radiative forcing is among the highest in the world over the Mediterranean summer (e.g. Le Treut et al., 1998; Haywood and Boucher, 2000; Lelieveld et al., 2002; Andreae et al., 2002). A Regional Climate Change Index (RCCI) has been defined by Giorgi (2006) to identify the most responsive regions to climate changes, or Hot-Spot. According to Giorgi (2006), the two most prominent Hot-Spots emerging from the RCCI analysis are the Mediterranean and North Eastern Europe regions.

In this paper, local monthly statistics of aerosol parameters retrieved on 2003 (one of the warmest of the last few years over the Mediterranean Regions) are used as input into a two-stream radiative transfer code, to quantify the anthropogenic aerosol impact to the radiative energy-balance of several land sites of the Mediterranean basin. In particular, aerosol parameters retrieved at Ispra, Venice, Oristano, Lecce, Lampedusa, and Crete, which span more than $17^{\circ}$ in longitude and $10^{\circ}$ in latitude and are differently affected by natural and anthropogenic aerosols, are used to in- vestigate the dependence of the anthropogenic aerosol impact on the site location. Size-distributions and refractive indices from sun/sky photometer measurements performed within AERONET are used to characterize aerosol properties at each site. In addition, mid-latitude standard atmosphere data by AFGL, MODIS derived data on solar surface albedo, and ISCCP cloud products are used to define the necessary input to a two-stream radiative transfer code. The anthropogenic aerosol DRE is calculated at each site in all-sky at the top of atmosphere (ToA), at the surface (sfc), and within the atmosphere, both at solar $(0.3-4 \mu \mathrm{m})$ and infrared (4$200 \mu \mathrm{m}$ ) wavelengths.

The AERONET instrumentation and the geographical location of the selected sites are briefly described in Sect. 2 . A brief description of the two-stream radiative transfer code and of the main input data is given in Sect. 3. A discussion on the aerosol properties of the selected AERONET site is also provided in Sect. 3. The results on the anthropogenic aerosol DREs are presented in Sect. 4. Some sensitivity tests are discussed in Sect. 5. Summary and conclusion are in Sect. 6.

\section{AERONET instrumentation and geographical loca- tion of the selected sites}

Cimel sun/sky radiometers operating within AERONET are automatic, robotically-operated instruments and consist of two detectors for the measurements of direct sun and sky radiance. Spectral observations of sun radiance are generally made at seven spectral channels: 340, 380, 440, 500, 675, 870 , and $1020 \mathrm{~nm}$, while measurements of sky radiance are made at 440, 675, 870, and $1020 \mathrm{~nm}$. Holben et al. (1998, 2001) give detailed descriptions of the instrument and data acquisition procedures. A flexible inversion algorithm (e.g. Dubovik and King, 2000; Dubovik et al., 2006) is used to retrieve columnar aerosol volume size distributions, and real and imaginary refractive indices ( $n$ and $k$ ) from direct-sun and diffuse-sky radiance measurements. Cloud-screened and quality-assured retrievals (level 2.0) from the Version 2 (V2) inversion algorithm are used in this study.

Figure 1 shows the geographical location of the selected AERONET sites: six stations that span more than $17^{\circ}$ in longitude and $10^{\circ}$ in latitude are considered. The Ispra site is located in the north-west of Italy $\left(45.80^{\circ} \mathrm{N}, 8.63^{\circ} \mathrm{E}\right.$, $235 \mathrm{~m}$ a.s.1.), near the Lago Maggiore and between two hills. The Venice sun photometer is located on Acqua Alta Oceanographic Tower (AAOT) in the northern Adriatic Sea, 8 nautical miles off the Venice Lagoon $\left(45.31^{\circ} \mathrm{N}, 12.51^{\circ} \mathrm{E}\right.$, $10 \mathrm{~m}$ a.s.1.). Both Ispra and Venice are northern Italian sites that are expected to be largely affected by anthropogenic pollution, as they are quite close to large cities and industrial areas. The Oristano site is situated on the west coast of Sardinia and the sunphotometer is located on the roof of the International Marine Center (IMC, $39.91^{\circ} \mathrm{N}, 8.5^{\circ} \mathrm{E}, 10 \mathrm{~m}$ a.s.1.). The Lecce sun photometer is located on the roof of the 


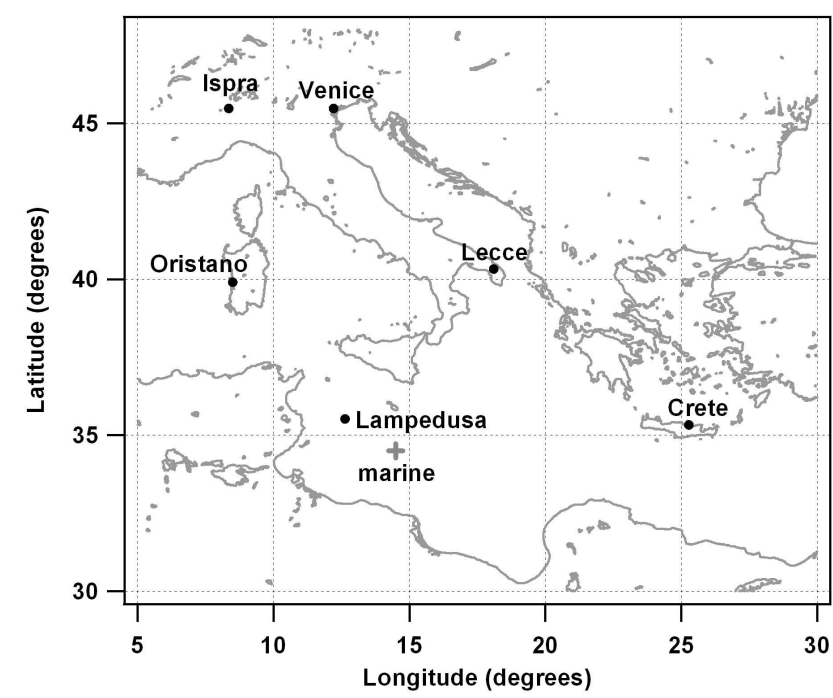

Fig. 1. Geographical location of the selected AERONET sites in the Central Mediterranean. The cross indicate a marine area $\left(34.50^{\circ} \mathrm{N}\right.$, $14.50^{\circ} \mathrm{E}$ ) off the Lampedusa island.

Physics Department of the University of Salento $\left(40.33^{\circ} \mathrm{N}\right.$, $18.10^{\circ} \mathrm{E}, 27 \mathrm{~m}$ a.s.l.). The site is in a suburban area, $6 \mathrm{~km}$ away from the city centre, and about $20 \mathrm{~km}$ from the Adriatic and the Ionian Sea, respectively. Lampedusa is a small Italian island located in the middle of the Sicilian Channel. The sun photometer is located in the area of the Military Base LORAM $\left(35.52^{\circ} \mathrm{N}, 12.63^{\circ} \mathrm{E}, 45 \mathrm{~m}\right.$ a.s.l. $)$. The Forth-Crete AERONET station is located in the northern coast of Crete $\left(35.19^{\circ} \mathrm{N}, 25.16^{\circ} \mathrm{E}, 20 \mathrm{~m}\right.$ a.s.l. $)$, a relatively isolated Greek island in the central-east Mediterranean Basin. In particular, the sun photometer is located on the roof of the $20 \mathrm{~m}$-high building of the National Center of Marine Research, which is at $100 \mathrm{~m}$ from the coast and $15 \mathrm{~km}$ east from Heraklion: the largest city in Crete. Both Lampedusa and Crete are expected to be more affected by natural aerosols being away from large sources of local pollution (Pace et al., 2006; Fotiadi et al., 2006).

\section{The two-stream radiative transfer model and input data}

A detailed description of the two-stream radiative transfer model used is given in Tafuro et al. (2007). The two stream method (e.g. Meador and Weaver, 1980) provides radiative fluxes at the boundary of homogeneous plane-parallel layers. Twenty homogeneous plane-parallel atmospheric layers are used in our model to account for the changes with altitude of the atmospheric parameters and components (e.g. pressure, temperature, gases, and particle distributions), and daily-averaged radiative fluxes are determined for the solar $(0.3-4 \mu \mathrm{m})$ and infrared $(4-200 \mu \mathrm{m})$ spectral region. In order to account for the diurnal Sun elevation changes, solar radiative transfer simulations are performed at five different Sun-elevations, which are characterized by $\cos (\zeta)=0.9,0.7$, $0.5,0.3$, and 0.1 , respectively, where $\zeta$ represents the solar zenith angle. Then, site-latitude and corresponding average Sun height above the horizon are used to determine fractional day-periods for each month. All available data are then properly weighted to get daily averaged solar radiative fluxes.

Vertical profiles of density, pressure, temperature, water vapour, oxygen, ozone, and well mixed trace-gases $\left(\mathrm{N}_{2} \mathrm{O}\right.$, $\mathrm{CO}_{2}, \mathrm{CO}$ and $\mathrm{CH}_{4}$ ) are prescribed by the US Air Force Geophysics Laboratory (AFGL) standard atmospheres for mid-latitude $\left(30-60^{\circ} \mathrm{N}\right)$ summer and winter with interpolations for the transitional seasons. Based on the air-density Rayleigh scattering is included and trace-gas concentrations in conjunction with pre-defined absorption coefficients are used to compute the trace-gas absorption.

\subsection{Surface properties}

Surface albedo monthly means are based on "black-sky" albedo (directional-hemispherical reflectance) and "whitesky" albedo (bihemispherical reflectance) data from the MODIS MOD43B3 products (Schaaf et al., 2002), which are provided every 16 days, at $1^{\circ} \times 1^{\circ}$ resolution for three broadbands: $0.3-0.7,0.3-5.0$, and $0.7-5.0 \mu \mathrm{m}$. Figure $2 \mathrm{a}-\mathrm{b}$ shows monthly averaged surface albedo values for the visible $(0.3-$ $0.7 \mu \mathrm{m})$ and infrared $(0.7-5.0 \mu \mathrm{m})$ spectral range, respectively, retrieved from the 2003-year MOD43B3 products and for $1^{\circ} \times 1^{\circ}$ cells centred at Ispra, Venice, Oristano, Lecce, Lampedusa, and Crete, respectively. Monthly averaged surface albedo values retrieved over a marine area $\left(34.50^{\circ} \mathrm{N}\right.$, $14.50^{\circ} \mathrm{E}$ ) off the Lampedusa island are also shown for comparison in Fig. 2 by grey crosses. We mention that percentage differences between 16-days and monthly averaged surface albedo values are on average smaller than few percents. Surface albedo values of Venice, Oristano, Lecce, Crete, and Lampedusa span the 0.02-0.09 and 0.09-0.17 range for the visible and infrared spectral range, respectively. These sites have the common properties to be rather close to the Sea and as a consequence the $1^{\circ} \times 1^{\circ}$ spatial MODIS regional average is quite affected by the low albedo of the surrounding Mediterranean Sea. The comparison in Fig. 2 of coastal site surface albedos with the one (grey crosses) retrieved over a marine area off the Lampedusa island supports last comment. On the contrary, Ispra that is located at the border of the Po Valley near the Lago Maggiore, is characterized by higher values spanning the $0.11-0.16$ and $0.20-0.26$ range for the solar and infrared spectral range, respectively. Note, that with (even only partial) snow cover much larger solar albedo values during winter at Ispra are possible.

A surface emissivity of 0.96 (and an albedo of $4 \%$ ) has been assumed in the far-infrared. 
Table 1. Number of AERONET measurements per month from which level 2 aerosol products are extracted. When level 2 AERONET products do not provide $n$ and $k$ values, the corresponding ones provided by level 1.5 AERONET products are used. The number of measurement days/month is given in brackets. Total measurements per month and per site are also given.

\begin{tabular}{lrrrrrrr}
\hline & Ispra & Venice & Oristano & Lecce & Lampedusa & Crete & Total \\
\hline January & $20(9)$ & $38(13)$ & $23(8)$ & $0(0)$ & $0(0)$ & $8(3)$ & $89(33)$ \\
February & $101(19)$ & $77(22)$ & $16(5)$ & $0(0)$ & $0(0)$ & $3(2)$ & $197(48)$ \\
March & $79(22)$ & $52(16)$ & $53(17)$ & $5(2)$ & $0(0)$ & $22(9)$ & $211(66)$ \\
April & $21(9)$ & $74(14)$ & $32(11)$ & $17(10)$ & $0(0)$ & $40(11)$ & $184(55)$ \\
May & $23(14)$ & $80(18)$ & $27(8)$ & $15(10)$ & $12(4)$ & $87(23)$ & $244(77)$ \\
June & $27(14)$ & $95(22)$ & $54(19)$ & $16(12)$ & $47(22)$ & $100(28)$ & $339(117)$ \\
July & $41(18)$ & $97(23)$ & $71(24)$ & $50(22)$ & $80(30)$ & $103(30)$ & $442(147)$ \\
August & $25(14)$ & $77(23)$ & $33(17)$ & $100(25)$ & $101(28)$ & $73(24)$ & $409(131)$ \\
September & $33(8)$ & $54(18)$ & $40(17)$ & $47(17)$ & $27(12)$ & $64(17)$ & $265(89)$ \\
October & $5(4)$ & $38(12)$ & $5(3)$ & $6(3)$ & $30(12)$ & $48(15)$ & $132(49)$ \\
November & $4(3)$ & $37(10)$ & $0(0)$ & $6(4)$ & $37(11)$ & $24(6)$ & $108(34)$ \\
December & $8(6)$ & $31(9)$ & $0(0)$ & $16(7)$ & $20(8)$ & $2(1)$ & $77(31)$ \\
Total & $387(140)$ & $750(200)$ & $354(129)$ & $278(112)$ & $354(127)$ & $574(169)$ & \\
\hline
\end{tabular}
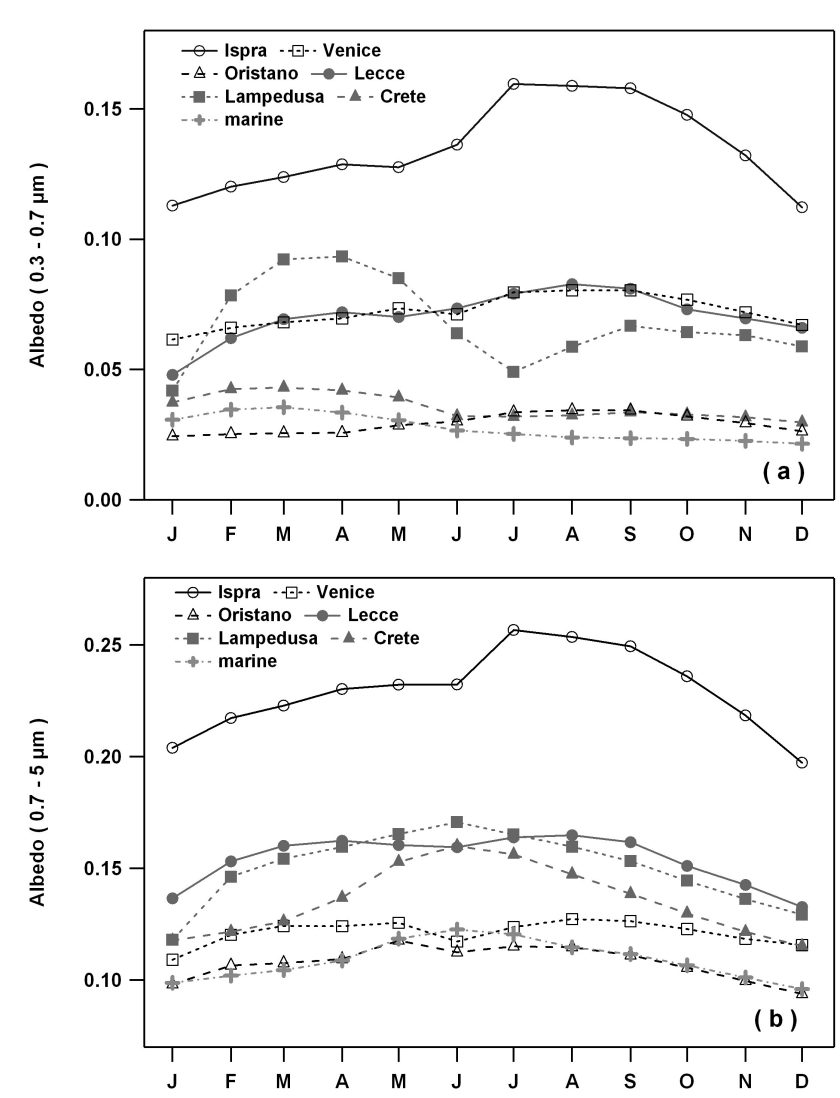

Fig. 2. Evolution of 2003 monthly mean surface albedos, at the selected sites and the marine area off the Lampedusa island in the (a) visible $(0.3-0.7 \mu \mathrm{m})$ and (b) near infrared $(0.7-5.0 \mu \mathrm{m})$, based on MODIS MOD43B3 products.
3.2 Aerosol properties at the selected sites from 2003 AERONET products

Particle number size distributions and real and imaginary refractive indices from AERONET sun/sky photometer measurements of the 2003 year, are used as input to the twostream radiative transfer model to characterize aerosol properties. Real and imaginary refractive indices are retrieved at $0.44,0.675,0.87$, and $1.02 \mu \mathrm{m}$, respectively. For the nearinfrared region of the solar spectrum, the AERONET refractive indices extracted for the wavelength at $1.02 \mu \mathrm{m}$ are applied. For the far-infrared spectral region the refractive indices for tropospheric aerosol (Paltridge and Platt, 1976) are used. A discussion on the accuracy of individual AERONET retrievals is reported in Dubovik et al. $(2000,2002)$ and it is also recalled in Tafuro et al. (2007). The number of measurements/month that have been properly weighted to retrieve monthly aerosol optical and microphysical properties at the selected AERONET sites, are given in Table 1. We recall that when level 2 AERONET products do not provide $n$ and $k$ values, the corresponding ones provided by level 1.5 AERONET products are used. The number of measurement days/month are reported in brackets. MIE calculations (assuming a spherical particle shape) are applied to translate the data on size, concentration and refractive indices into AODs (a measure of the magnitude of the aerosol extinction due to scattering and absorption), single scattering albedo (SSA) values (a measure of the relative importance of absorption and scattering), and asymmetry-factors (a measure of the angular distribution of the scattering radiation). AOD, SSA, and asymmetry-factor $(g)$ represent the main parameters generally used to understand the complex interaction of aerosols with radiation. Figure $3 \mathrm{a}-\mathrm{c}$ shows monthly averaged AODs at $550 \mathrm{~nm}$ for Ispra and Venice, for 
Oristano and Lecce, and for Lampedusa and Crete, respectively. Error bars in Fig. 3 represent \pm 1 standard deviation (std. dev.) and are based on the daily AOD variability. Arrows highlight in each plot monthly averaged AOD values based on less than 4 measurement days (i.e. less than $10 \%$ of month days) to better evaluate the statistical significance of mean values and standard deviations. The variability of AOD monthly means is generally much larger than the accuracy of its retrieval ( \pm 0.01 , Holben et al., 1998) at all sites. The selected sites are grouped by latitude band in Fig. 3 and it is worth noting that the differences between mean monthly AOD values are on average lower than corresponding standard deviations at the sites characterized by rather close latitude values. Figure 3 highlights that daily AOD variations are on average larger at the northern Mediterranean sites of this study. Crete represents the site where monthly standard deviations are on average smaller all year round. We also observe from Fig. 3 that monthly mean AODs are on average larger on spring-summer (April-September) at all sites. This result is likely due to the larger solar flux and to the lack of rainy days that generally occur over the Mediterranean basin in summer favouring the production of photochemical smog and the accumulation, in the absence of rain, of local and long range transported atmospheric particles. Forest fires that mostly on summer occur over southern Europe also represent a contributing factor (Pace et al., 2005; Tafuro et al., 2008). The recent paper on the spatial and temporal variability in aerosol properties over the Mediterranean basin by Papadimas et al. (2008) that is based on 6-year (2000-2006) MODIS data, support last comments. The AOD interannual variability in the Mediterranean basin has also been analyzed by Papadimas et al. (2008). Hence, that paper is rather useful to evaluate the specificity of the 2003-year AOD values (used in this study) with respect to the corresponding ones over the 2000-2006 periods. In addition, the paper by Papadimas et al. (2008) can allow inferring to what extent the AERONET sites of our study are representative of the Central Mediterranean.

Aerosol size is a key parameter to separate natural from man-made aerosol and hence to infer the anthropogenic contribution to the total aerosol load. The anthropogenic aerosol is dominated by fine-mode particles, while natural aerosol contains a substantial component of coarse-mode particles (e.g. Kaufman et al., 2001). The AERONET inversion algorithm retrieves aerosol volume size distributions in the range of sizes $0.05 \mu \mathrm{m} \leq r<15 \mu \mathrm{m}$, where $r$ represents the particle radius. In accordance with previous studies, all particles with radius $0.05 \mu \mathrm{m} \leq r<0.5 \mu \mathrm{m}$ are considered fine, while those with $0.5 \mu \mathrm{m} \leq r \leq 15 \mu \mathrm{m}$ are considered coarse. This last definition is commonly used to define the AOD due to fine and coarse mode particles and therefore the fine-mode fraction $\eta$, i.e. the ratio between the fine-mode and the total optical depth at $550 \mathrm{~nm} . \eta$ is used to infer the role of natural and anthropogenic particles to the total aerosol load (e.g. Santese et al., 2008). Monthly averaged $\eta$ values \pm 1 std. dev. (based
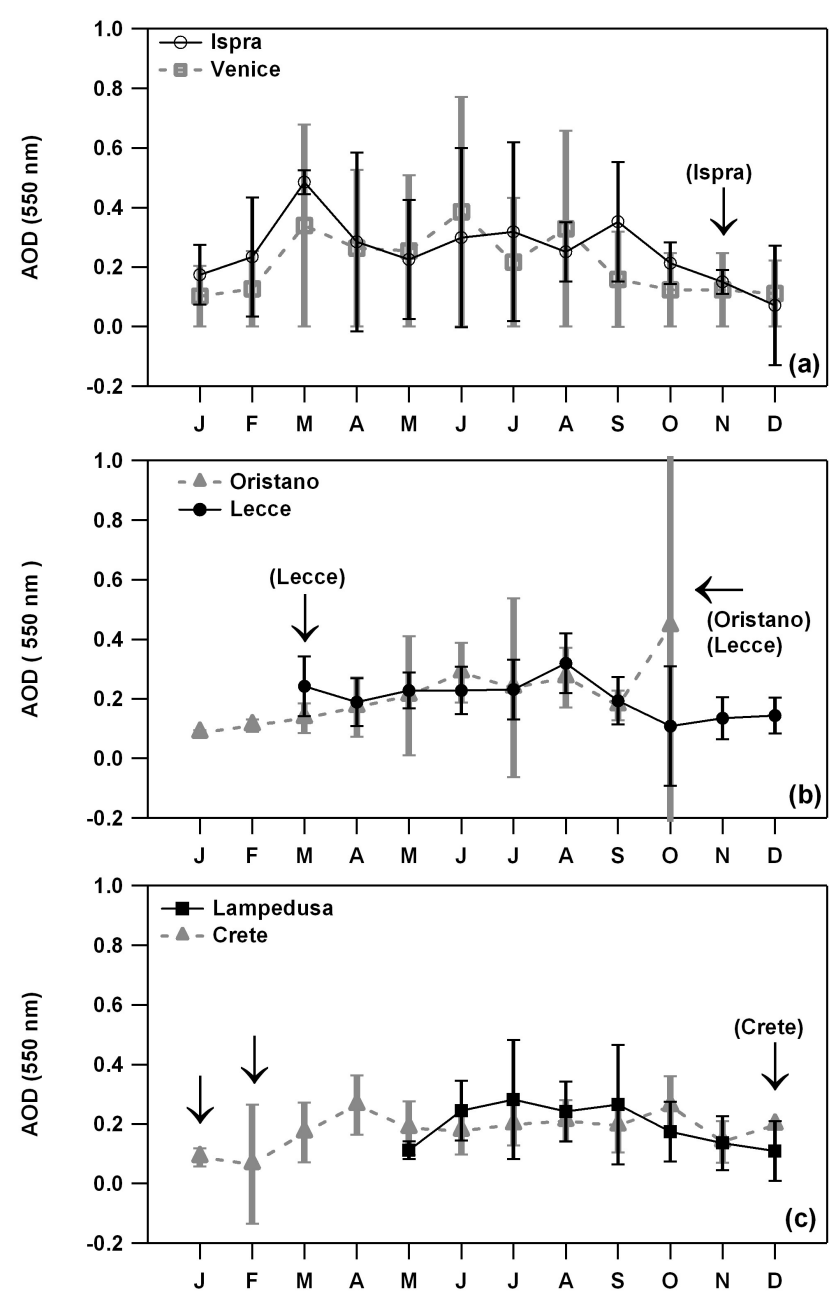

Fig. 3. Evolution of 2003 monthly averages of the total aerosol optical depth (AOD) at $550 \mathrm{~nm}$, recomputed from AERONET-derived aerosol particle size distributions and refractive indices, for (a) Ispra and Venice, (b) Oristano and Lecce, and (c) Lampedusa and Crete. Error bars represent \pm 1 std. dev. and are based on the daily AOD variability. Arrows highlight in each plot monthly averaged AOD values based on less than 4 measurement days (i.e. less than $10 \%$ of month days).

on the daily $\eta$ variability) at $550 \mathrm{~nm}$ are plotted in Fig. 4ac. The comparison of AOD and $\eta$ values provides a clear picture on how aerosol properties vary from site to site and how the selected sites of this study are differently affected by coarse- and fine-mode particles and hence, by natural and anthropogenic aerosols. Figure 3 reveals that AODs are on average larger at Venice and Ispra. In addition, $\eta$ values that span the $0.86-0.94$ and $0.81-0.93$ range at Ispra and Venice, respectively (Fig. 4a) indicate that the rather high aerosol load is mainly due to fine mode particles, probably of anthropogenic origin both sites being rather close to large cities and industrial areas. In addition, $\eta$-standard deviations that on average are rather small at Ispra and Venice (Fig. 4a) allow 

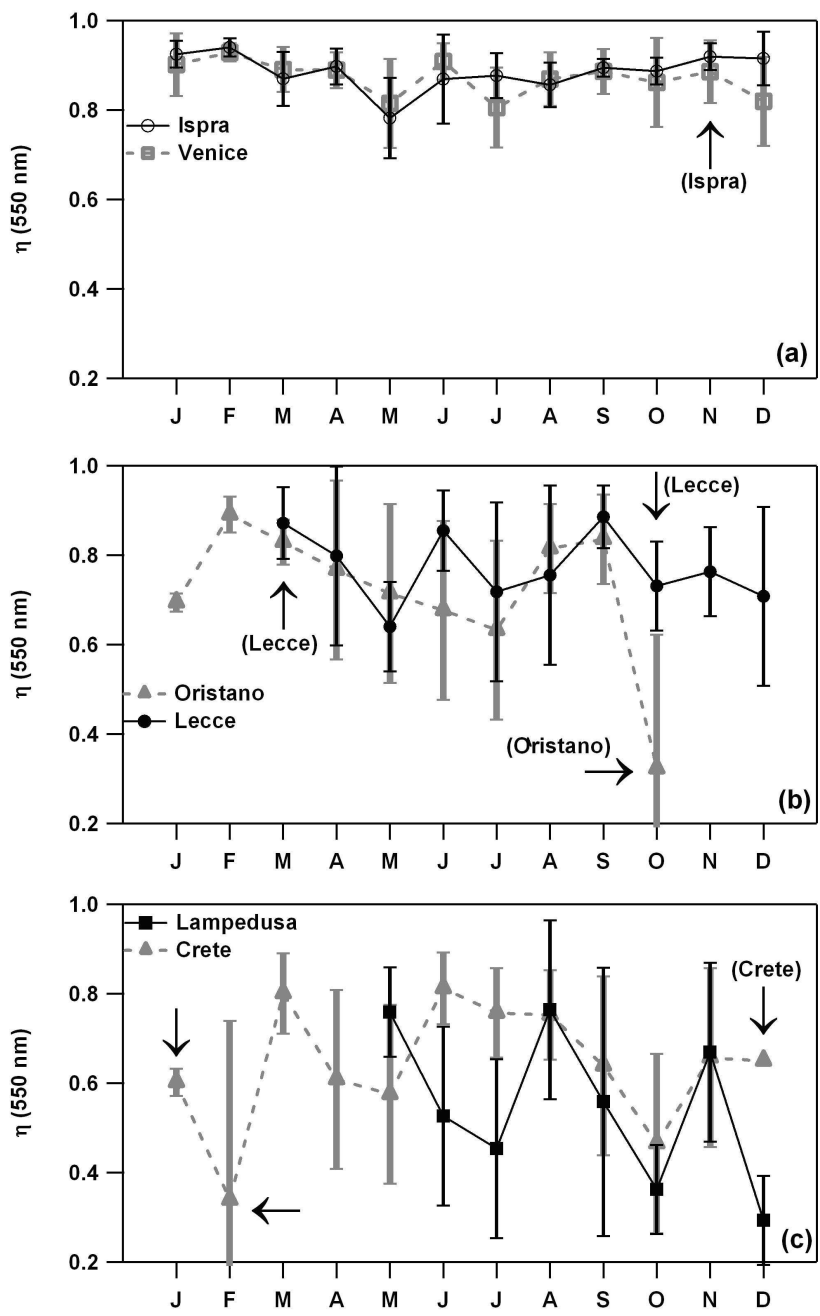

Fig. 4. Evolution of 2003 monthly averaged fine-mode fractions $(\eta)$ at $550 \mathrm{~nm}$, recomputed from AERONET-derived aerosol particle size distributions and refractive indices, for (a) Ispra and Venice, (b) Oristano and Lecce, and (c) Lampedusa and Crete. Error bars represent \pm 1 std. dev. and are based on the daily $\eta$ variability. Arrows highlight in each plot monthly averaged $\eta$ values based on less than 4 measurement days (i.e. less than $10 \%$ of month days).

inferring that anthropogenic aerosols dominate all through the year at both sites. Hence, the high AOD daily variability revealed by the plots of Fig. 3a may be due to the high variability of the anthropogenic sources (urban/industrial) that affect the aerosol load of north Italy. The rather high AOD observed on March both at Ispra and Venice, is probably due to a rather strong pollution event (being $\eta \cong 0.9$ at both sites) that on March has affected all north Italy. Monthly means of March aerosol parameters are based on a large number of measurements (79 and 52, at Ispra and Venice, respectively), which have been retrieved from 22 and 16 measurement days at Ispra and Venice, respectively (Table 1). Figures $4 \mathrm{~b}$ and $\mathrm{c}$ show that Lecce and Oristano, and Crete and Lampedusa, respectively are characterized by $\eta$ values span- ning the $0.3-0.9$ range. These last $\eta$ values that are on average smaller than those retrieved at Venice and Ispra, are probably due to the fact that Lecce, Oristano, Crete, and Lampedusa are more affected by desert and sea salt aerosols. In fact, monthly-averaged $\eta$ values reach smallest values at Crete and Lampedusa both sites being surrounded by the Sea and rather close to desert areas. The high daily variability of $\eta$-values revealed by the large width of standard deviation bars of Fig. 4b-c, allows inferring that the southern Mediterranean sites of this study, also are quite affected by the anthropogenic aerosol in addition to the natural aerosol (such as dust and sea-salt). The rather low $\eta$ value retrieved on October at Oristano is mostly due to the strong Sahara dust outbreak that occurred over the Mediterranean basin on 1-2 October. $\eta$ and AOD values of Figs. $4 \mathrm{c}$ and 3c, respectively indicate that Lampedusa and Crete have also been affected by dust events on October, in accordance with back-trajectory plots. Figures $3 \mathrm{c}$ and $4 \mathrm{c}$ show that the Lampedusa aerosol load was also quite affected by Sahara dust particles on July 2003 (Tafuro et al., 2006): the AOD reaches a rather high value while $\eta$ reaches a rather small value.

It is worth mentioning that according to Bellouin et al. (2005), anthropogenic aerosols alone are associated with $\eta$ values at $550 \mathrm{~nm}$ larger than $0.83 \pm 0.05$, while $0.35<\eta<0.83$ are associated with mixtures of anthropogenic and natural aerosols. In situ observations of the AOD fraction from aerosol particles smaller than $1 \mu \mathrm{m}$ in diameter (accumulation-mode fraction) have been used by Bellouin et al. (2005) to define the above $\eta$ threshold values. Hence, in accordance with Bellouin's criteria and our above reported discussion, the Ispra and Venice aerosol load is made of anthropogenic aerosols alone. In contrast, mixtures of anthropogenic and natural aerosols characterize the aerosol load at Oristano, Lecce, Lampedusa, and Crete.

Figure 5a-c shows monthly averaged SSA values \pm 1 std. dev. (based on the daily SSA variability) at 550 $\mathrm{nm}$ for Ispra and Venice, for Oristano and Lecce, and for Lampedusa and Crete, respectively. The differences between monthly SSA values are on average lower than \pm 1 std. dev. at the sites characterized by rather close latitude values. SSA values vary within the $0.84-0.98$ range, in accordance with the variability range observed by Yu et al. (2006) over Europe. We also observe from Fig. 5a, that SSA values span the 0.84-0.96 and 0.92-0.96 range at Ispra and Venice, respectively. In addition, Fig. 5a shows that SSA values have at Ispra a marked seasonality that is characterized by smaller and larger SSA values on winter and summer, respectively. The smaller SSA values retrieved at Ispra on winter months show the relative importance of absorption processes by anthropogenic particles on these months. We believe that winter house-heating emissions and meteorological conditions contribute to the Ispra-SSA seasonality. Venice SSA values are also smaller on winter months. In contrast to Fig. 5a results, Figs. 5b and c show that the relative importance of absorption by aerosol particles is on average larger 


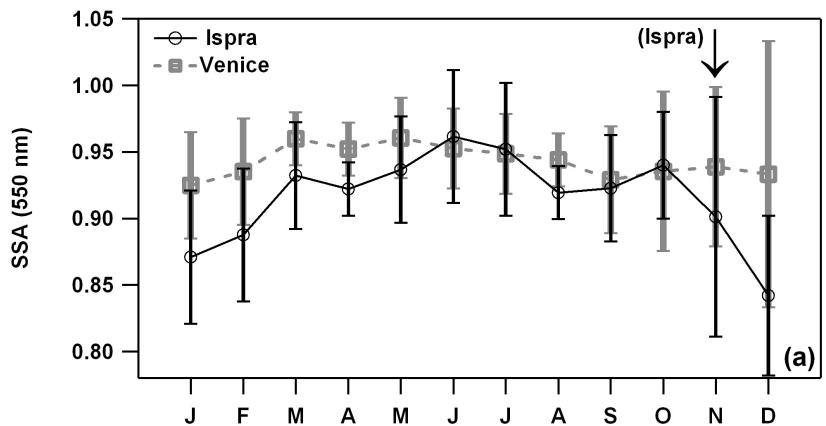

Table 2. Monthly values of the factor $f$.
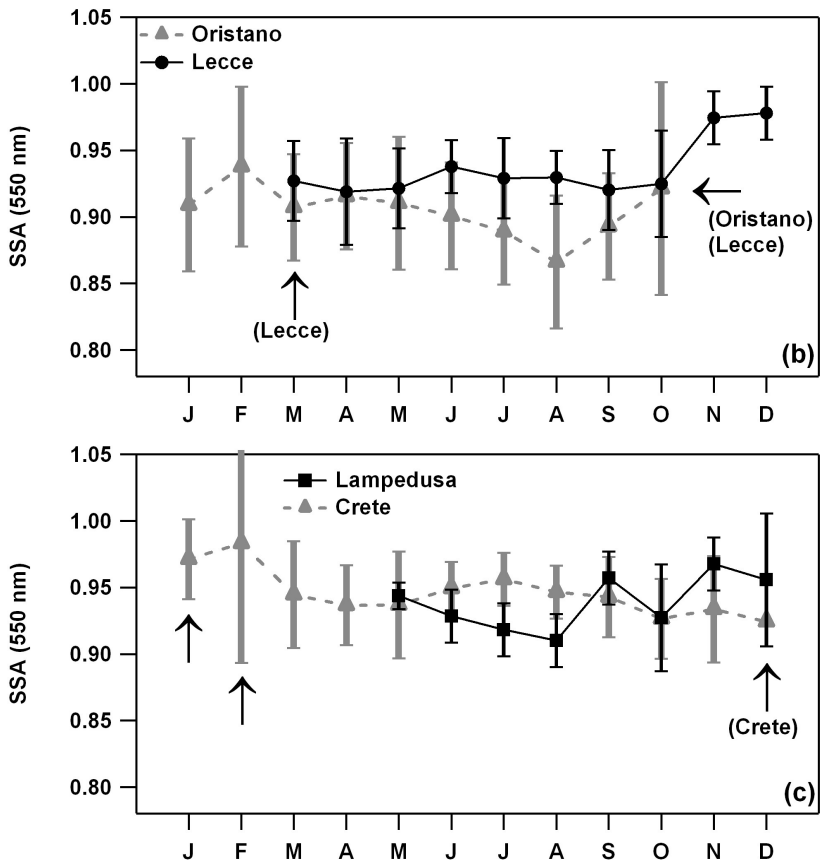

Fig. 5. Evolution of 2003 monthly averages of the total single scattering albedo (SSA) at $550 \mathrm{~nm}$ recomputed from AERONETderived aerosol particle size distributions and refractive indices, for (a) Ispra and Venice, (b) Oristano and Lecce, and (c) Lampedusa and Crete. Error bars represent \pm 1 std. dev. and are based on the daily SSA variability. Arrows highlight in each plot monthly averaged SSA values based on less than 4 measurement days (i.e. less than $10 \%$ of month days).

on spring-summer (SS) at Lecce and Lampedusa: SS and autumn-winter (AW, October to March) average values are $0.93 \pm 0.02$ and $0.95 \pm 0.03$ at both sites. As mentioned, the larger solar flux and the lack of rainy days that, on average, similarly affect Lecce and Lampedusa on summer, is quite responsible for these results (Pace et al., 2006; Santese et al., 2008). Summer forest fires represent a contributing factor (Pace et al., 2005). However, it is worth mentioning that the variability range of monthly averaged SSA values is comparable to the theoretical accuracy of its retrieval ( \pm 0.03 for AOD $(440 \mathrm{~nm})>0.2$ and $\pm(0.05-0.07)$ for AOD $(440 \mathrm{~nm}) \leq 0.2$; Dubovik et al., 2000) at all sites, even for the larger AOD values at Ispra during the winter.

\begin{tabular}{lcccccc}
\hline$f$-values & Ispra & Venice & Oristano & Lecce & Lampedusa & Crete \\
\hline January & 0.91 & 0.90 & 0.80 & 0.74 & 0.56 & 0.66 \\
February & 0.91 & 0.92 & 0.88 & 0.78 & 0.67 & 0.59 \\
March & 0.88 & 0.87 & 0.81 & 0.68 & 0.61 & 0.54 \\
April & 0.82 & 0.79 & 0.82 & 0.66 & 0.73 & 0.65 \\
May & 0.79 & 0.78 & 0.77 & 0.63 & 0.66 & 0.53 \\
June & 0.67 & 0.68 & 0.63 & 0.73 & 0.52 & 0.79 \\
July & 0.80 & 0.80 & 0.70 & 0.80 & 0.64 & 0.76 \\
August & 0.78 & 0.81 & 0.69 & 0.86 & 0.59 & 0.84 \\
September & 0.85 & 0.84 & 0.83 & 0.79 & 0.76 & 0.73 \\
October & 0.82 & 0.79 & 0.75 & 0.66 & 0.64 & 0.58 \\
November & 0.89 & 0.78 & 0.80 & 0.45 & 0.68 & 0.57 \\
December & 0.85 & 0.75 & 0.68 & 0.64 & 0.48 & 0.66 \\
\hline
\end{tabular}

Asymmetry-factor plots in Fig. 6a-c show that monthly averaged $g$-values vary within the $0.63-0.74$ range. Error bars in Fig. 6 represent \pm 1 std. dev. and are based on the daily $g$ variability. According to Yu et al. (2006) the theoretical accuracy of its retrieval is \pm 0.02 . As it is well known, $g$ is equal to 1 for completely forward scattering and is equal to zero for symmetric (e.g. Rayleigh) scattering. The plots of Fig. 6a-c suggest that the angular distribution of the scattering radiation by aerosol particles follows a seasonal trend that varies from site to site. In particular, Fig. 6a shows that, on average, $g$-values reach smaller values $(0.66 \pm 0.02)$ on autumnwinter at Ispra, since fine-mode particles are predominant on AW at this site (Fig. 4a). In contrast, Crete $g$-values appear to reach smaller values $(0.65 \pm 0.01)$ on summer when finemode particles are on average predominant (Fig. 4c). These last results may indicate that the aerosol properties are differently affected by seasons at Ispra and Crete as a consequence of the different contribution of aerosol sources. It is worth mentioning that Yu et al. (2006) found $g=0.66 \pm 0.03$ (annual average) over Europe.

\subsection{Anthropogenic aerosol properties at the selected sites}

In accordance with previous studies (e.g. Bellouin et al., 2005; Kaufman et al., 2005; Chung et al., 2005; Yu et al., 2006), also in this paper the anthropogenic aerosol contribution is associated with a fraction of the sub-micron size particles. In particular, the AERONET volume particle size distribution referring to particles with radius $0.05 \mu \mathrm{m} \leq r<0.5 \mu \mathrm{m}$ is first used to calculate the number concentration of finemode aerosols $N_{f}(r)$. Potential anthropogenic contributions to the coarse size mode are ignored. Then, only a fraction $f$ of $N_{f}(r)$ is considered of anthropogenic origin in accordance with the following relationship

$N_{a}(r)=f \cdot N_{f}(r)$

where $N_{a}(r)$ is the number concentration of anthropogeniconly submicron aerosol particles. Monthly $f$-values that are given in Table 2 for each selected site of this study 

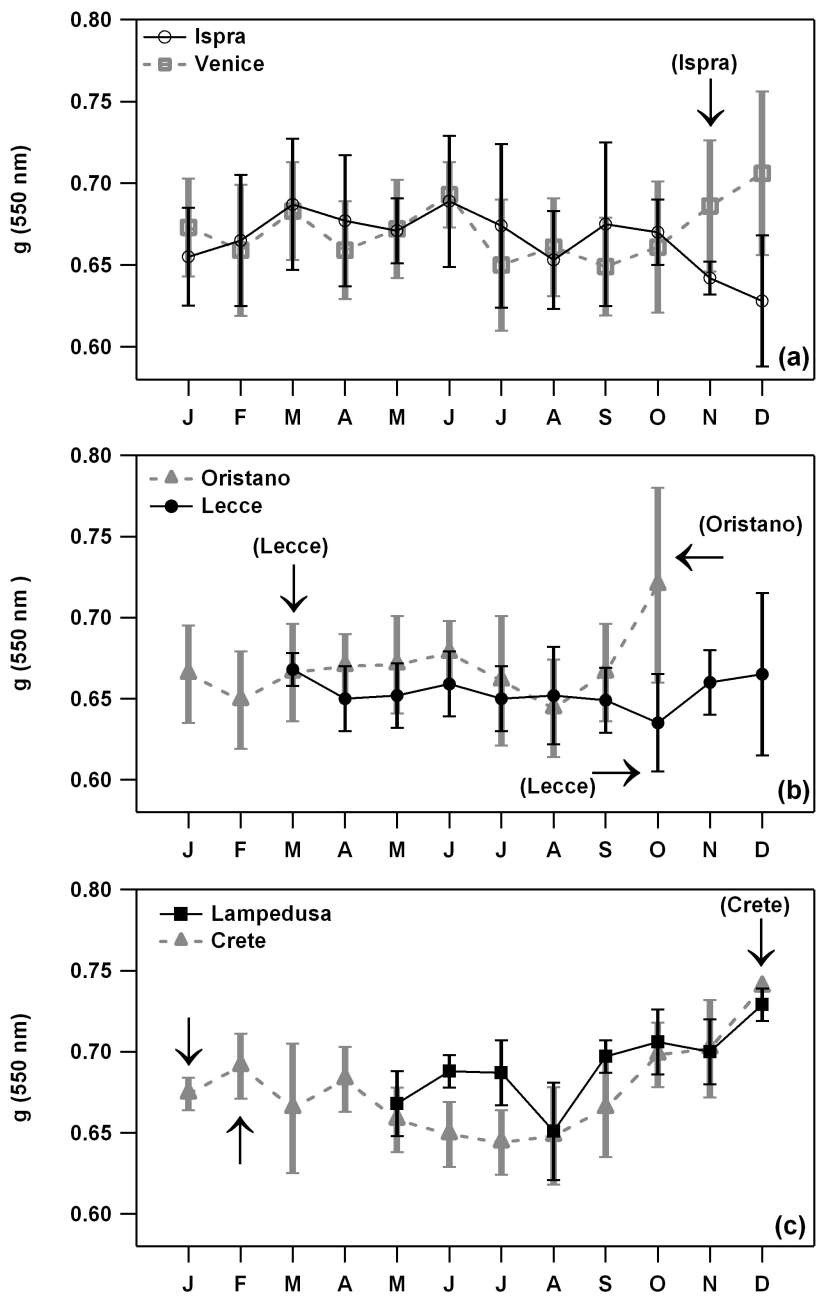

Fig. 6. Evolution of 2003 monthly averages of the total asymmetryfactor $(g)$ at $550 \mathrm{~nm}$, recomputed from AERONET-derived aerosol particle size distributions and refractive indices, for (a) Ispra and Venice, (b) Oristano and Lecce, and (c) Lampedusa and Crete. Error bars represent \pm 1 std. dev. and are based on the daily $g$ variability. Arrows highlight in each plot monthly averaged $g$ values based on less than 4 measurement days (i.e. less than $10 \%$ of month days).

are considered constant with particle size in the submicron fraction. $f$-values are based on LMDzT3.3 (Reddy et al., 2005) global model-simulations (Schulz et al., 2006). In particular, inventories for global emissions of aerosols and pre-cursor gases for the years 2000 (current conditions) and 1750 (pre-industrial conditions) (Dentener et al., 2006; Stier et al., 2007) were used in the General Circulation Model LMDzT3.3 to calculate $f$-values.

MIE calculations are applied to translate the data on the number concentrations of anthropogenic aerosols (Eq. 1) into aerosol optical depth, single-scattering albedo, and asymmetry factor of anthropogenic particles. Refractive indices are not considered dependent on particle size. A discussion on this last assumption is given in Sect. 5 .
Mean values \pm 1 std. dev., and minimum (Min) and maximum (Max) values of monthly means for annual and semiannual time-periods of anthropogenic aerosol parameters are investigated next. Anthropogenic aerosol optical depths $\left(\mathrm{AOD}_{\mathrm{a}}\right)$ at $550 \mathrm{~nm}$ are listed in Table 3 for all sites. In accordance with the discussion of Sect. 3.2, Table 3 shows that $\mathrm{AOD}_{\mathrm{a}}$ values are on average larger at Ispra and Venice and smaller at Crete and Lampedusa, the last two sites being more affected by desert and marine aerosols. In particular, $\mathrm{AOD}_{\mathrm{a}}$ values span the $0.06-0.37$ range at Ispra and the $0.02-0.11$ and $0.01-0.13$ range at Lampedusa and Crete, respectively: the sites less affected by anthropogenic particles (mean percentage $\mathrm{AOD}_{\mathrm{a}} / \mathrm{AOD}=40 \%$ ).

We know that a criterion different than that of Eq. (1) could be used to infer $\mathrm{AOD}_{\mathrm{a}}$ values but, each criterion may have its weakness since only in situ samplings can allow determining anthropogenic particle contributions. In particular, we believe that Bellouin et al. (2005) criteria that have been reported in the previous paragraph, tend to overestimate the anthropogenic aerosol component. Kaufman et al. (2005) considered the total aerosol optical depth made by its anthropogenic (air pollution and smoke aerosol), dust, and baseline marine components and suggested a method to calculate $\mathrm{AOD}_{\mathrm{a}}$ by using MODIS and AERONET retrievals to calculate dust, and baseline marine components. We have found that the $\mathrm{AOD}_{\mathrm{a}}$ values of Table 3 are in good accordance with the values calculated according to Kaufman et al. (2005). The fraction of natural AOD from the Georgia Tech/Goddard Global Ozone Chemistry Aerosol Radiation and Transport (GOCART) model (Chin et al., 2002) was used by Chung et al. (2005) to estimate worldwide the anthropogenic aerosol component from combined MODIS and AERONET AODs retrieved for the period 2001-2003. The latitude dependence of the $\mathrm{AOD}_{\mathrm{a}}$ values retrieved in this paper appears in fair accordance with the one reported by Chung et al. (2005) for the month of April.

Spring-summer and autumn-winter $\mathrm{AOD}_{\mathrm{a}}$ average values are also given in Table 3 to facilitate the comparison between different sites. Table 3 reveals that $\mathrm{SS} \mathrm{AOD}_{a}$ values are more than $30 \%$ larger than $\mathrm{AW} \mathrm{AOD}_{\mathrm{a}}$ values at all sites with the exception of Ispra where the anthropogenic fraction is $\sim 80 \%$ of the whole aerosol optical depth in both SS and AW. In contrast, at Lampedusa, $30 \%$ and $40 \%$ of the aerosol load is of anthropogenic origin on AW and SS, respectively. According to Kaufman et al. (2005) anthropogenic fractions of $\sim 80 \%$ at AODs $>0.2$ are typical of polluted sites, while anthropogenic fraction of $\sim 40 \%$ are typical of sites affected by mixed aerosol types. In accordance with the above comment, Table 3 data show that the Mediterranean coastal island sites far away from larger cities and/or industrial area such as Lampedusa and Crete are more affected by mixed aerosol types, contrary to Venice, Oristano and Lecce, which are coastal sites closer to the European continent, the main source of pollution advected over the Mediterranean basin (e.g. Lelieveld et al., 2002). The results 
Table 3. Basic statistics of $\mathrm{AOD}_{\mathrm{a}}, \mathrm{AOD}_{\mathrm{a}} / \mathrm{AOD}(\%), \mathrm{SSA}_{\mathrm{a}}$, and $g_{a}$ parameters. Mean values and standard deviations are based on monthly values. April-September and October-March monthly values are used to calculate Mean SS and Mean AW values, respectively and corresponding standard deviations.

\begin{tabular}{lrrrrrr}
\hline & Ispra & Venice & Oristano & Lecce & Lampedusa & Crete \\
\hline AOD & & & & & & \\
Mean & $(0.19 \pm 0.08)$ & $(0.15 \pm 0.07)$ & $(0.11 \pm 0.03)$ & $(0.11 \pm 0.05)$ & $(0.07 \pm 0.03)$ & $(0.08 \pm 0.04)$ \\
Min-Max & $0.06-0.37$ & $0.07-0.26$ & $0.05-0.15$ & $0.05-0.21$ & $0.02-0.11$ & $0.01-0.13$ \\
Mean SS & $(0.20 \pm 0.05)$ & $(0.18 \pm 0.05)$ & $(0.12 \pm 0.02)$ & $(0.13 \pm 0.04)$ & $(0.09 \pm 0.02)$ & $(0.10 \pm 0.03)$ \\
Mean AW & $(0.18 \pm 0.11)$ & $(0.12 \pm 0.07)$ & $(0.08 \pm 0.03)$ & $(0.08 \pm 0.05)$ & $(0.04 \pm 0.02)$ & $(0.06 \pm 0.03)$ \\
AODa $/$ AOD\% & & & & & & \\
Mean & $(79 \pm 9)$ & $(71 \pm 7)$ & $(57 \pm 16)$ & $(53 \pm 11)$ & $(36 \pm 13)$ & $(43 \pm 14)$ \\
Min-Max & $61-88$ & $62-85$ & $25-82$ & $36-68$ & $18-55$ & $14-62$ \\
Mean SS & $(76 \pm 11)$ & $(68 \pm 5)$ & $(58 \pm 10)$ & $(57 \pm 11)$ & $(40 \pm 11)$ & $(50 \pm 12)$ \\
Mean AW & $(82 \pm 5)$ & $(75 \pm 8)$ & $(57 \pm 24)$ & $(47 \pm 10)$ & $(28 \pm 13)$ & $(35 \pm 12)$ \\
SSA & & & & & & \\
Mean & $(0.93 \pm 0.04)$ & $(0.96 \pm 0.01)$ & $(0.95 \pm 0.02)$ & $(0.97 \pm 0.01)$ & $(0.98 \pm 0.01)$ & $(0.98 \pm 0.01)$ \\
Min-Max & $0.85-0.98$ & $0.94-0.98$ & $0.92-0.98$ & $0.95-0.99$ & $0.96-0.99$ & $0.95-1.00$ \\
Mean SS & $(0.95 \pm 0.02)$ & $(0.96 \pm 0.01)$ & $(0.95 \pm 0.02)$ & $(0.96 \pm 0.01)$ & $(0.97 \pm 0.01)$ & $(0.98 \pm 0.00)$ \\
Mean AW & $(0.91 \pm 0.05)$ & $(0.95 \pm 0.01)$ & $(0.95 \pm 0.02)$ & $(0.97 \pm 0.02)$ & $(0.99 \pm 0.01)$ & $(0.98 \pm 0.02)$ \\
$g_{a}$ & & & & & & \\
Mean & $(0.65 \pm 0.02)$ & $(0.66 \pm 0.02)$ & $(0.63 \pm 0.01)$ & $(0.63 \pm 0.02)$ & $(0.65 \pm 0.03)$ & $(0.64 \pm 0.03)$ \\
Min-Max & $0.61-0.68$ & $0.62-0.69$ & $0.61-0.65$ & $0.59-0.66$ & $0.62-0.69$ & $0.60-0.72$ \\
Mean SS & $(0.66 \pm 0.02)$ & $(0.65 \pm 0.02)$ & $(0.63 \pm 0.01)$ & $(0.62 \pm 0.01)$ & $(0.64 \pm 0.02)$ & $(0.62 \pm 0.01)$ \\
Mean AW & $(0.65 \pm 0.02)$ & $(0.67 \pm 0.02)$ & $(0.63 \pm 0.01)$ & $(0.63 \pm 0.03)$ & $(0.67 \pm 0.03)$ & $(0.66 \pm 0.03)$ \\
\hline
\end{tabular}

by five global circulation models, including aerosol representations (Reddy et al., 2005; Takemura et al., 2005; Collins et al., 2002; Stier et al., 2005; Kirkevag and Iversen, 2002) and using the same emissions have shown that on a global, annual average, $47 \pm 9 \%$ of the AOD over land is due to anthropogenic aerosols and that the anthropogenic fraction is $54 \pm 16 \%$ over Eurasia $\left(90^{\circ} \mathrm{N}-30^{\circ} \mathrm{N}, 30^{\circ} \mathrm{W}-180^{\circ} \mathrm{E}\right)$. These results are in fair accordance with the mean value of this paper $(60 \pm 20 \%)$ referring to 5 different sites of the Mediterranean basin (Table 3 ).

Mean values, minimum and maximum values, and SS- and AW-mean values of the anthropogenic-SSA $\left(\mathrm{SSA}_{\mathrm{a}}\right)$ and $-g$ $\left(g_{a}\right)$ at $550 \mathrm{~nm}$ are also given in Table 3 . We observe from Table 3 that the mean $\mathrm{SSA}_{\mathrm{a}}$ value that is $0.98 \pm 0.01$ both at Crete and Lampedusa, is equal to $0.93 \pm 0.04$ at Ispra as a consequence of the larger absorption by anthropogenic particles occurring at this site.

\subsection{Aerosol vertical distribution}

The profile plotted in Fig. 7 is used to represent the aerosol vertical distribution at all sites of this study. Seasonal variations are neglected. The lowermost $2 \mathrm{~km}$ layer of the Fig. 7 profile contributes by $\sim 90 \%$ to the total AOD. The vertical profile of Fig. 7 can be considered representative of the mean aerosol vertical distribution over southern Europe in accordance with the paper by Guibert et al. (2005). Although sensitivity studies demonstrated a relatively weak impact of the

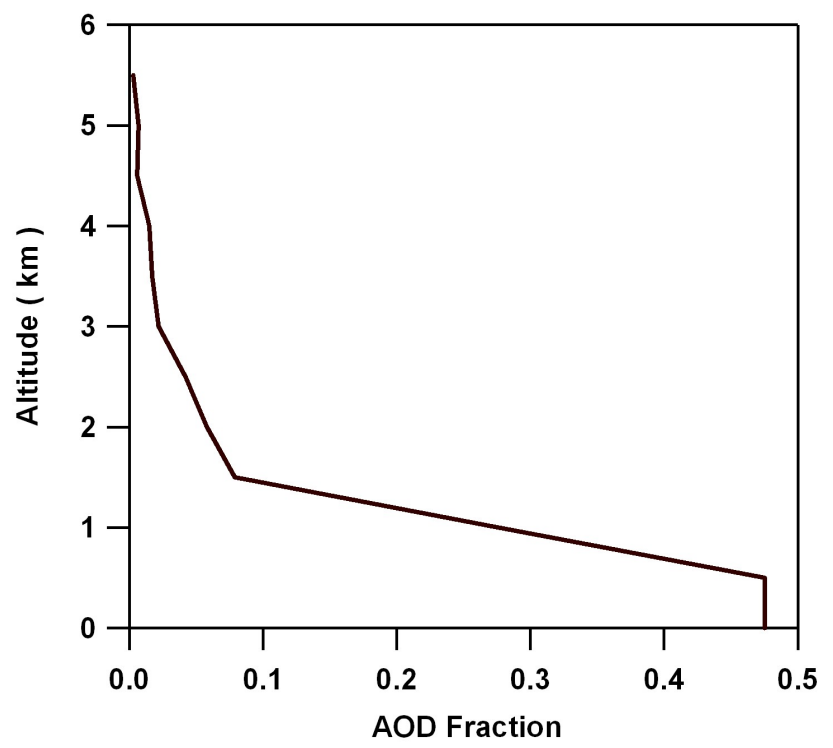

Fig. 7. Vertical profile of the aerosol optical depth fraction.

aerosol vertical distribution on radiative forcing at the surface or at clear-sky conditions (e.g. Tafuro et al., 2007), some impact can be expected under cloudy-skies for ToA DRE $\mathrm{D}_{\mathrm{a}}$, as (already slightly) absorbing aerosols (e.g. dust and pollution) above lower placed clouds (e.g. stratus, inversions) can even lead to a ToA warming for low $\mathrm{DRE}_{\mathrm{a}}$ values. 


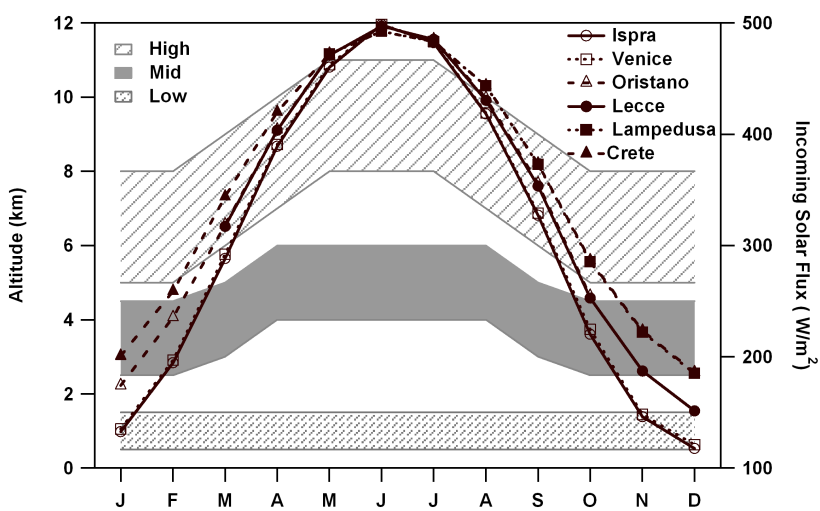

Fig. 8. Monthly evolution in 2003 of the incoming solar flux (symbols) at the selected sites. Dashed areas represent the altitude location of low-, medium-, and high-level clouds.

\subsection{Cloud cover}

Necessary cloud properties are based on the multi-year (1984-2004) ISCCP D2 statistics (Rossow and Schiffer, 1999), which supplies data defined by a multi-annual average (1984-2004) of monthly means of cloud scene optical depth for high-, mid-, and low-cloud cover. ISCCP cloud climatology data have been interpolated from $2.5^{\circ}$ to $1^{\circ}$. Inverse distance weights of the next four corners values define the applied cloud properties at each site. Figure 7 shows as a function of the months of the year, the altitude location of high-, mid-, and low-level clouds that has been used in this paper. Cloud optical depth (COD) and cloud cover values as a function of the months of the year are plotted in Fig. 9a and $\mathrm{b}$, respectively for each site.

\section{Anthropogenic aerosol direct radiative effect esti- mates}

All-sky anthropogenic aerosol direct radiative effects $\left(\mathrm{DRE}_{\mathrm{a}}\right)$ are calculated at each site at the top of atmosphere (ToA), at the surface (sfc), and within the atmosphere (AF), both at solar $(0.3-4 \mu \mathrm{m})$ and infrared $(4-200 \mu \mathrm{m})$ wavelengths. To this end, it is worth recalling that AERONET measurements are essentially clear-sky and that it is assumed in this work that the average aerosol properties derived from AERONET can be extrapolated to all sky conditions.

The ToA DRE summarizes the impact to the entire EarthAtmosphere-System, while the surface DRE captures the impact on exchange processes between the atmosphere and the Earth's surface. The anthropogenic atmospheric forcing $\left(A F_{a}\right)$ that is defined as the difference between ToA and surface aerosol $\mathrm{DRE}_{\mathrm{a}}$ is an indicator of aerosol effects on atmospheric dynamics. The anthropogenic-aerosol forcing efficiency $\mathrm{AFE}_{\mathrm{a}}$ (aerosol $\mathrm{DRE}_{\mathrm{a}}$ per unit anthropogenic optical
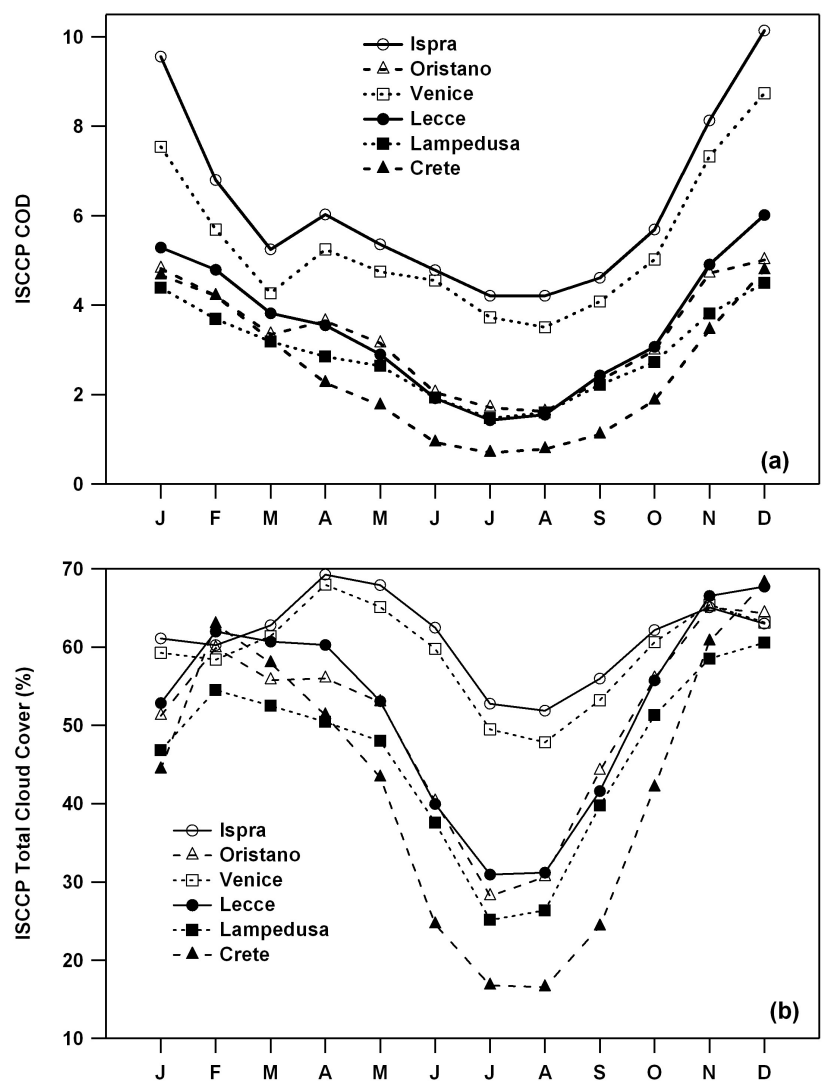

Fig. 9. (a) Cloud optical depth (COD) and (b) cloud cover percentages as a function of the months of the year based on the multi-year (1984-2004) ISCCP D2 statistics at different sites.

depth) that is mainly dependent on aerosol size and composition is also calculated at each site.

4.1 Anthropogenic ToA and surface DREs at solar wavelengths $(0.3-4 \mu \mathrm{m})$

Figure 10a-c and Fig. 11a-c show the monthly evolution of the all-sky DRE by anthropogenic aerosols at the ToA and at the surface (sfc), respectively. The anthropogenic AF is plotted in Fig. 12a-c. Anthropogenic DRE efficiencies at the ToA and at the surface (sfc) are plotted in Figs. 13a-c and $14 \mathrm{a}-\mathrm{c}$, respectively. The selected sites are grouped by latitude band in Figs. 10-14 and it is worth noting that the monthly evolution of all plotted parameters is quite dependent on latitude. Mean ( \pm 1 std. dev.), maximum (Max) and minimum (Min) values, and SS and AW mean-values of the investigated parameters are given on Table 4 a to show the variability range of each parameter and facilitate comparison between different sites.

ToA- and sfc-DRE $E_{a}$ monthly-means are negative all through the year at all sites. This demonstrates a cooling of the Earth-Atmosphere-System by aerosols, as extra solar radiation is reflected back to space. Aerosol associated 

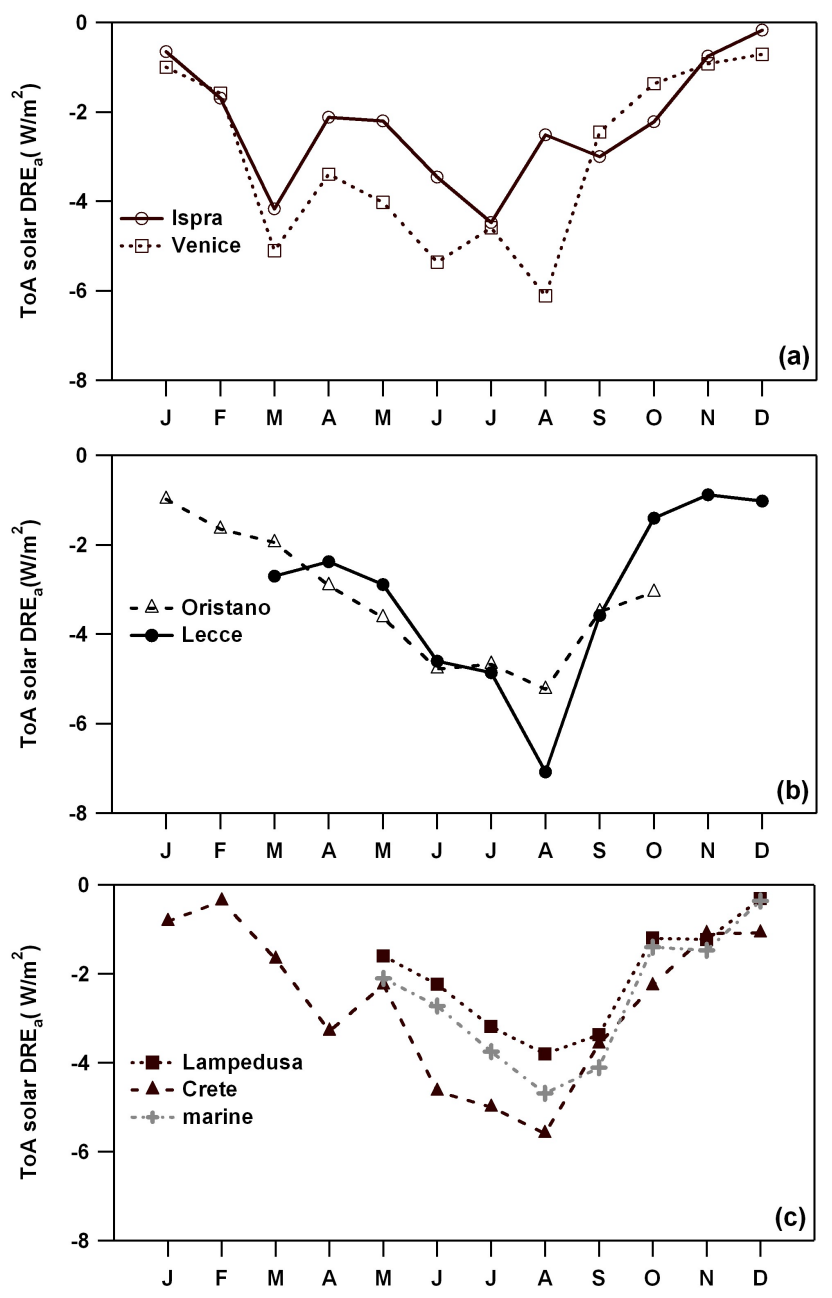

Fig. 10. Monthly evolution in 2003 of the solar $(0.3-4 \mu \mathrm{m})$ all-sky ToA-DRE by anthropogenic particles at (a) Ispra and Venice, (b) Oristano and Lecce, and (c) Lampedusa, Crete, and the marine area off the Lampedusa island.

reductions of the downward solar radiation at the Earth's surface are larger, as aerosols not only scatter but also absorb solar radiation. According to Ramanathan et al. (2001), for strongly absorbing aerosols $(\mathrm{SSA}<0.95)$ the surface forcing far exceeds the ToA forcing. In accordance with the above comments, Figs. 10 and 11 allow inferring that sfcanthropogenic-aerosol DREs are on average more than 1.3 larger than ToA-DRE $\mathrm{a}_{\mathrm{a}}$ values. $\mathrm{SSA}_{\mathrm{a}}$ values are, on average, smaller at Ispra $\left(0.85 \leq \mathrm{SSA}_{\mathrm{a}} \leq 0.98\right)$. Then, the differences between ToA- and sfc-DRE $\mathrm{a}$ values are larger at Ispra, where the $\left(\right.$ sfc-DRE $\left._{\mathrm{a}}\right) /\left(\mathrm{ToA}_{\mathrm{ARE}}\right)$ ratio varies within the $1.4 \div 6.6$ range. In contrast, the $\left(\mathrm{sfc}_{\mathrm{DRE}}\right) /\left(\mathrm{ToA}_{\mathrm{a}} \mathrm{DRE} \mathrm{a}_{\mathrm{a}}\right)$ ratio varies within the $1.1 \div 1.5$ range at Lampedusa, where $\mathrm{SSA}_{\mathrm{a}}$ values vary within the $0.96 \div 0.99$ range.

A marked seasonal trend of the ToA- and sfc-DRE with larger absolute values on spring-summer and smaller absolute values on autumn-winter is observed at most of
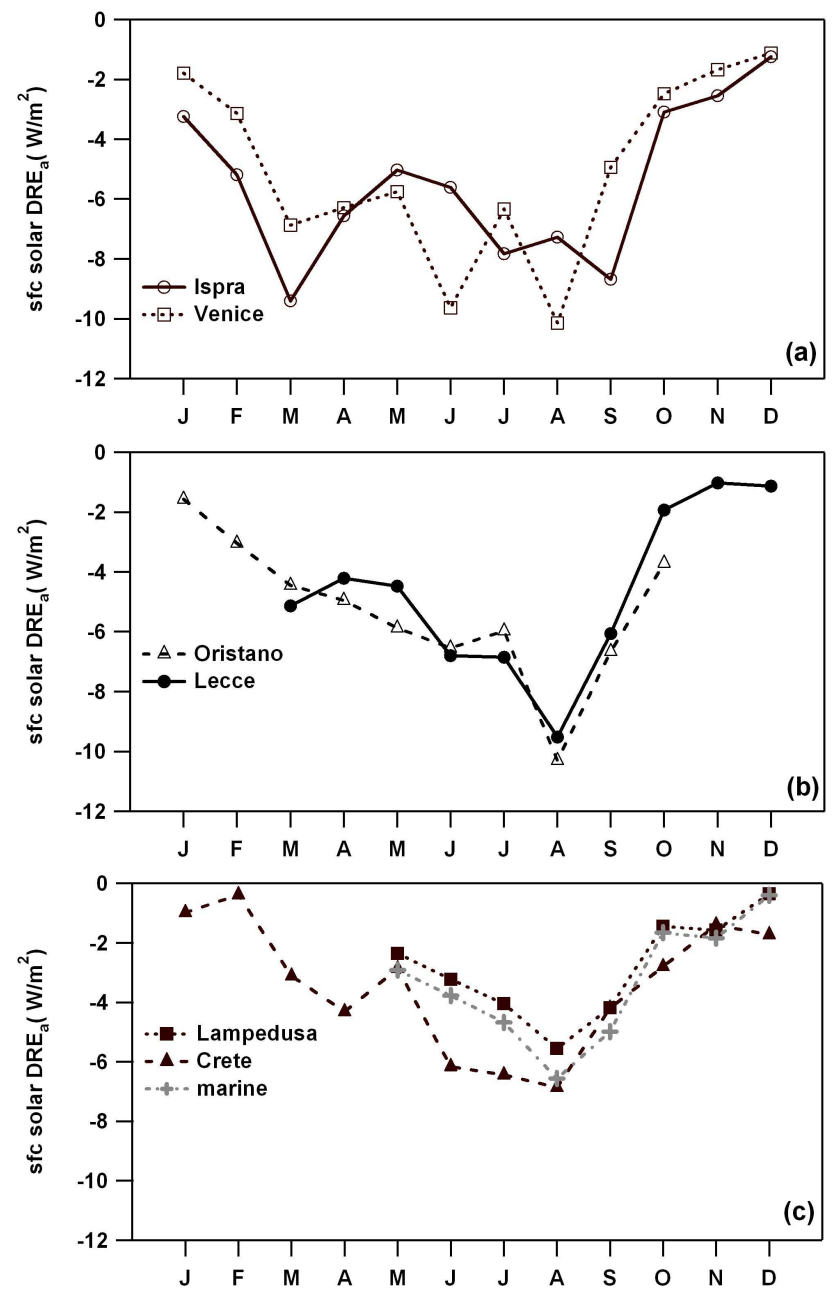

Fig. 11. Monthly evolution in 2003 of the solar $(0.3-4 \mu \mathrm{m})$ allsky sfc-DRE by anthropogenic particles at (a) Ispra and Venice, (b) Oristano and Lecce, and (c) Lampedusa, Crete, and the marine area off the Lampedusa island.

the sites. ToA-DRE $\mathrm{a}_{\mathrm{a}}$ values span the $-(0.2 \div 4.2) \mathrm{W} \mathrm{m}^{-2}$ and the $-(2.3 \div 7.1) \mathrm{W} \mathrm{m}^{-2}$ range, on $\mathrm{AW}$ and $\mathrm{SS}$, respectively (Fig. 10a-c). In contrast, sfc-DRE ${ }_{a}$ values span the $-(0.4 \div 9.4) \mathrm{W} \mathrm{m}^{-2}$ and the $-(2.3 \div 10.3) \mathrm{W} \mathrm{m}^{-2}$ range, on AW and SS, respectively (Fig. 11a-c). Figure 8 (symbols) shows the monthly-means of the incoming solar flux at the six selected sites, to better infer the aerosol role on the seasonal trend of the ToA- and sfc-DRE $\mathrm{a}_{\mathrm{a}}$. The incoming solar flux reaches the highest value $\left(\sim 500 \mathrm{~W} \mathrm{~m}^{-2}\right)$ on June at all sites and the smallest value $\left(\sim 120 \mathrm{~W} \mathrm{~m}^{-2}\right)$ on December both at Ispra and Venice. Hence, the seasonal cycle of the available solar radiation that reaches higher values on SS at all sites, is primarily responsible for the seasonal variability of the aerosol $\mathrm{DRE}_{\mathrm{a}}$. The seasonal changes of the aerosol properties are a contributing factor and are mainly responsible for the asymmetric trend of the aerosol $\mathrm{DRE}_{\mathrm{a}}$ seasonal variability. Figures 10 and 11 show that the aerosol $\mathrm{DRE}_{\mathrm{a}}$ follows a rather similar seasonal trend at 
Table 4a. Basic statistics (mean value \pm 1 std. dev. and minimum and maximum values and Spring-Summer and Autumn-Winter mean values \pm 1 std. dev.) of the parameters used to evaluate the DRE by anthropogenic particles at solar wavelengths.

\begin{tabular}{|c|c|c|c|c|c|c|}
\hline$\left(\mathrm{W} \mathrm{m}^{-2}\right)$ & Ispra & Venice & Oristano & Lecce & Lampedusa & Crete \\
\hline \multicolumn{7}{|l|}{$\mathrm{DRE}_{\mathrm{a}}^{\mathrm{ToA}}$} \\
\hline Mean & $-(2.3 \pm 1.3)$ & $-(3.0 \pm 1.9)$ & $-(3.2 \pm 1.4)$ & $-(3.1 \pm 2.0)$ & $-(2.1 \pm 1.2)$ & $-(2.6 \pm 1.8)$ \\
\hline Min; Max & $-(4.5 ; 0.2)$ & $-(6.1 ; 0.7)$ & $-(5.2 ; 1.0)$ & $-(7.1 ; 0.9)$ & $-(3.8 ; 0.3)$ & $-(5.6 ; 0.4)$ \\
\hline Mean SS & $-(3.0 \pm 0.9)$ & $-(4.3 \pm 1.3)$ & $-(4.1 \pm 0.9)$ & $-(4.2 \pm 1.7)$ & $-(3.0 \pm 0.9)$ & $-(4.1 \pm 1.2)$ \\
\hline Mean AW & $-(1.6 \pm 1.4)$ & $-(1.8 \pm 1.6)$ & $-(1.9 \pm 0.9)$ & $-(1.5 \pm 0.9)$ & $-(0.9 \pm 0.5)$ & $-(1.2 \pm 0.7)$ \\
\hline \multicolumn{7}{|l|}{$\mathrm{DRE}_{\mathrm{a}}^{\mathrm{sfc}}$} \\
\hline Mean & $-(5.5 \pm 2.6)$ & $-(5.0 \pm 3.0)$ & $-(5.3 \pm 2.4)$ & $-(4.7 \pm 2.8)$ & $-(2.8 \pm 1.7)$ & $-(3.4 \pm 2.2)$ \\
\hline Min; Max & $-(9.4 ; 1.2)$ & $-(10.1 ; 1.1)$ & $-(10.3 ; 1.6)$ & $-(9.5 ; 1.0)$ & $-(5.6 ; 0.4)$ & $-(6.9 ; 0.4)$ \\
\hline Mean SS & $-(6.8 \pm 1.4)$ & $-(7.2 \pm 2.2)$ & $-(6.7 \pm 1.9)$ & $-(6.3 \pm 1.9)$ & $-(3.9 \pm 1.2)$ & $-(5.1 \pm 1.6)$ \\
\hline Mean AW & $-(4.1 \pm 2.9)$ & $-(2.8 \pm 2.1)$ & $-(3.2 \pm 1.2)$ & $-(2.3 \pm 1.9)$ & $-(1.1 \pm 0.7)$ & $-(1.7 \pm 1.1)$ \\
\hline \multicolumn{7}{|l|}{$\mathrm{AF}_{\mathrm{a}}$} \\
\hline Mean & $3.2 \pm 1.6$ & $2.0 \pm 1.2$ & $2.1 \pm 1.3$ & $1.6 \pm 0.1$ & $0.7 \pm 0.5$ & $0.8 \pm 0.5$ \\
\hline Min; Max & $0.8 ; 5.7$ & $0.4 ; 4.3$ & $0.6 ; 5.1$ & $0.1 ; 2.5$ & $0.04 ; 1.8$ & $0.02 ; 1.5$ \\
\hline Mean SS & $3.8 \pm 1.3$ & $2.9 \pm 1.1$ & $2.6 \pm 1.4$ & $2.1 \pm 0.3$ & $0.9 \pm 0.4$ & $1.1 \pm 0.4$ \\
\hline Mean AW & $2.5 \pm 1.7$ & $1.0 \pm 0.5$ & $1.3 \pm 0.9$ & $0.8 \pm 1.1$ & $0.2 \pm 0.2$ & $0.5 \pm 0.5$ \\
\hline \multicolumn{7}{|l|}{$\mathrm{AFE}_{\mathrm{a}}^{\mathrm{To} A}$} \\
\hline Mean & $-(11.6 \pm 5.6)$ & $-(19.1 \pm 6.9)$ & $-(29.4 \pm 8.0)$ & $-(26.6 \pm 7.2)$ & $-(29.5 \pm 6.6)$ & $-(31.4 \pm 10.0)$ \\
\hline Min; Max & $-(20.1 ; 3.1)$ & $-(33.1 ; 10.4)$ & $-(45.5 ; 19.2)$ & $-(36.6 ; 15.7)$ & $-(39.1 ; 20.1)$ & $-(43.5 ; 12.7)$ \\
\hline Mean SS & $-(15.3 \pm 4.2)$ & $-(24.3 \pm 5.2)$ & $-(34.0 \pm 6.6)$ & $-(31.9 \pm 4.9)$ & $-(33.2 \pm 4.1)$ & $-(39.6 \pm 4.1)$ \\
\hline Mean AW & $-(7.9 \pm 4.3)$ & $-(14.0 \pm 3.5)$ & $-(22.6 \pm 4.0)$ & $-(20.1 \pm 4.8)$ & $-(23.5 \pm 5.5)$ & $-(23.2 \pm 6.6)$ \\
\hline \multicolumn{7}{|l|}{$\mathrm{AFE}_{\mathrm{a}}^{\mathrm{sfc}}$} \\
\hline Mean & $-(28.9 \pm 7.2)$ & $-(31.9 \pm 9.8)$ & $-(48.0 \pm 11.0)$ & $-(39.4 \pm 11.6)$ & $-(39.0 \pm 10.7)$ & $-(40.5 \pm 12.0)$ \\
\hline Min-Max & $-(43.1 ; 19.9)$ & $-(45.7 ; 16.5)$ & $-(67.5 ; 33.5)$ & $-(52.0 ; 17.4)$ & $-(50.8 ; 22.8)$ & $-(56.0 ; 20.3)$ \\
\hline Mean SS & $-(35.0 \pm 4.4)$ & $-(40.2 \pm 4.7)$ & $-(54.6 \pm 7.3)$ & $-(46.9 \pm 3.3)$ & $-(45.6 \pm 5.7)$ & $-(50.1 \pm 5.4)$ \\
\hline Mean AW & $-(22.8 \pm 2.4)$ & $-(23.7 \pm 5.3)$ & $-(38.2 \pm 7.6)$ & $-(28.0 \pm 9.8)$ & $-(28.1 \pm 6.9)$ & $-(31.0 \pm 8.4)$ \\
\hline
\end{tabular}

Table 4b. Basic statistics (mean value \pm 1 std. dev. and minimum and maximum values and Spring-Summer and Autumn-Winter mean values \pm 1 std. dev.) of the parameters used to evaluate the DRE by anthropogenic particles at infrared wavelengths.

\begin{tabular}{|c|c|c|c|c|c|c|}
\hline$\left(\mathrm{W} \mathrm{m}^{-2}\right)$ & Ispra & Venice & Oristano & Lecce & Lampedusa & Crete \\
\hline \multicolumn{7}{|l|}{$\mathrm{DRE}_{\mathrm{a}}^{\mathrm{To} A}$} \\
\hline Mean & $0.03 \pm 0.03$ & $0.03 \pm 0.03$ & $0.05 \pm 0.04$ & $0.04 \pm 0.04$ & $0.015 \pm 0.015$ & $0.025 \pm 0.022$ \\
\hline Min; Max & $0 ; 0.08$ & $0 ; 0.11$ & $0 ; 0.11$ & $0 ; 0.1$ & $0 ; 0.04$ & $0 ; 0.06$ \\
\hline Mean SS & $0.05 \pm 0.02$ & $0.06 \pm 0.03$ & $0.07 \pm 0.03$ & $0.06 \pm 0.03$ & $0.02 \pm 0.01$ & $0.04 \pm 0.01$ \\
\hline Mean AW & $0.008 \pm 0.007$ & $0.01 \pm 0.01$ & $0.01 \pm 0.01$ & $0.008 \pm 0.009$ & $0.0 \pm 0.0$ & $0.007 \pm 0.008$ \\
\hline \multicolumn{7}{|l|}{$\mathrm{DRE}_{\mathrm{a}}^{\mathrm{sfc}}$} \\
\hline Mean & $0.21 \pm 0.08$ & $0.18 \pm 0.08$ & $0.18 \pm 0.06$ & $0.16 \pm 0.08$ & $0.12 \pm 0.06$ & $0.14 \pm 0.11$ \\
\hline Min; Max & $0.07 ; 0.35$ & $0.08 ; 0.35$ & $0.09 ; 0.26$ & $0.06 ; 0.33$ & $0.02 ; 0.2$ & $0.01 ; 0.33$ \\
\hline Mean SS & $0.23 \pm 0.07$ & $0.22 \pm 0.08$ & $0.21 \pm 0.04$ & $0.21 \pm 0.08$ & $0.15 \pm 0.04$ & $0.22 \pm 0.10$ \\
\hline & \multicolumn{6}{|c|}{$\mathrm{AFE}_{\mathrm{a}}^{\mathrm{To} A}$} \\
\hline Mean & $0.14 \pm 0.12$ & $0.18 \pm 0.14$ & $0.35 \pm 0.26$ & $0.26 \pm 0.20$ & $0.17 \pm 0.12$ & $0.23 \pm 0.16$ \\
\hline Min; Max & $0.02 ; 0.35$ & $0.03 ; 0.44$ & $0.05 ; 0.77$ & $0.04 ; 0.57$ & $0.04 ; 0.33$ & $0.02 ; 0.44$ \\
\hline Mean SS & $0.23 \pm 0.10$ & $0.29 \pm 0.12$ & $0.51 \pm 0.21$ & $0.39 \pm 0.15$ & $0.25 \pm 0.06$ & $0.37 \pm 0.07$ \\
\hline $\begin{array}{c}\text { Mean AW } \\
\text { AFE }_{\mathrm{a}}^{\mathrm{ffc}}\end{array}$ & $0.04 \pm 0.01$ & $0.07 \pm 0.04$ & $0.11 \pm 0.05$ & $0.08 \pm 0.03$ & $0.04 \pm 0.0$ & $0.10 \pm 0.06$ \\
\hline Mean & $1.0 \pm 0.2$ & $1.1 \pm 0.5$ & $1.5 \pm 0.2$ & $1.3 \pm 0.2$ & $1.5 \pm 0.3$ & $1.5 \pm 0.6$ \\
\hline Min; Max & $0.8 ; 1.4$ & $0.8 ; 1.4$ & $1.2 ; 1.9$ & $0.9 ; 1.6$ & $1.0 ; 1.8$ & $0.7 ; 2.6$ \\
\hline Mean SS & $1.0 \pm 0.2$ & $1.1 \pm 0.2$ & $1.5 \pm 0.2$ & $1.4 \pm 0.2$ & $1.7 \pm 0.1$ & $1.9 \pm 0.5$ \\
\hline Mean AW & $1.0 \pm 0.1$ & $1.1 \pm 0.2$ & $1.4 \pm 0.2$ & $1.2 \pm 0.2$ & $1.3 \pm 0.2$ & $1.1 \pm 0.3$ \\
\hline
\end{tabular}


Venice, Oristano, Lecce, Lampedusa, and Crete: maximum aerosol $\mathrm{DRE}_{\mathrm{a}}$ values at the ToA and sfc are reached on August at these sites. The anthropogenic AOD that reaches the highest value on August at Venice, Oristano, Lecce, Lampedusa, and Crete, is quite responsible for these last results. Similarly, we believe that the rather high ToA- and sfc$\mathrm{DRE}_{\mathrm{a}}$ value observed on March at Ispra is quite affected by the anthropogenic AOD that at this site reaches the highest value on March. It is also worth noting that anthropogenic AODs take at Ispra largest mean values both on AW and SS: $(0.18 \pm 0.11)$ and $(0.20 \pm 0.05)$, respectively. As a consequence, Table $4 \mathrm{a}$ shows that the sfc-DRE $\mathrm{a}$ takes a rather small mean value at Ispra both on AW $\left(-(4.1 \pm 2.9) \mathrm{W} \mathrm{m}^{-2}\right)$ and SS $\left(-(6.8 \pm 1.4) \mathrm{W} \mathrm{m}^{-2}\right)$. In contrast, sfc-DRE $\mathrm{a}_{\mathrm{a}}$ values are larger $\left(-(3.9 \pm 1.2) \mathrm{W} \mathrm{m}^{-2}\right.$ and $-(1.1 \pm 0.7) \mathrm{W} \mathrm{m}^{-2}$ on SS and AW, respectively) at Lampedusa that is the site less affected by anthropogenic particles all year round. Lampedusa $\mathrm{AOD}_{\mathrm{a}}$ mean-values are $0.09 \pm 0.02$ and $0.04 \pm 0.02$ on SS and AW, respectively. The above reported discussion reveals that monthly-means of ToA- and sfc-DRE $\mathrm{a}_{\mathrm{a}}$ values can significantly vary from site to site, as a consequence of the high spatial and temporal variability of the anthropogenic aerosol load over the Mediterranean basin.

Chung et al. (2005) have recently provided a global estimate of the all-sky DRE by anthropogenic particles, by integrating MODIS, 1999-2001 ISCPP, and 2001-2003 AERONET observations with models of aerosol chemistry, transport and radiative transfer. According to Chung et al. (2005) annual-mean ToA and sfc $\mathrm{DRE}_{\mathrm{a}}$ values span the $-(2 \div 4) \mathrm{W} \mathrm{m}^{-2}$ and $-(6 \div 12) \mathrm{W} \mathrm{m}^{-2}$ range, respectively over the Mediterranean Regions, in fair accordance with the results of this paper (Table 4a).

Anthropogenic AF plots (Fig. 12a-c) reveal that Ispra, Venice, and Oristano represent the sites where $\mathrm{AF}_{\mathrm{a}}$ values are on average larger, as a consequence of the fact that at these sites, $\mathrm{AOD}_{\mathrm{a}}$ and $\mathrm{SSA}_{\mathrm{a}}$ take on average larger and smaller values, respectively, all year round (Table 3). Anthropogenic AFs vary within the $(0.8 \div 5.7),(0.4 \div 4.3)$, and $(0.6 \div 5.1) \mathrm{W} \mathrm{m}^{-2}$ range at Ispra, Venice, and Oristano, respectively. On the contrary, anthropogenic AFs vary within the $(0.1 \div 2.5),(0.04 \div 1.8)$, and $(0.02 \div 1.5) \mathrm{W} \mathrm{m}^{-2}$ range at Lecce, Lampedusa and Crete, respectively. Anthropogenic $\mathrm{AF}$ values of this paper appear to be in fair accordance with annual mean values provided by Chung et al. (2005) over the Mediterranean Regions. As mentioned, the AF is an indicator of aerosol effects on atmospheric dynamics. In fact, the cooling of the Earth's surface from absorbing aerosols and the consequential warming of the atmosphere may cause a flattened vertical temperature profile in the troposphere, which is expected to slow the hydrological cycle, reduce evaporation from the surface and reduce cloud formation (Kaufman et al., 2002). In accordance with the results of this paper, anthropogenic aerosol effects on the atmospheric dynamics are expected to be less important over the southern Mediterranean Regions.
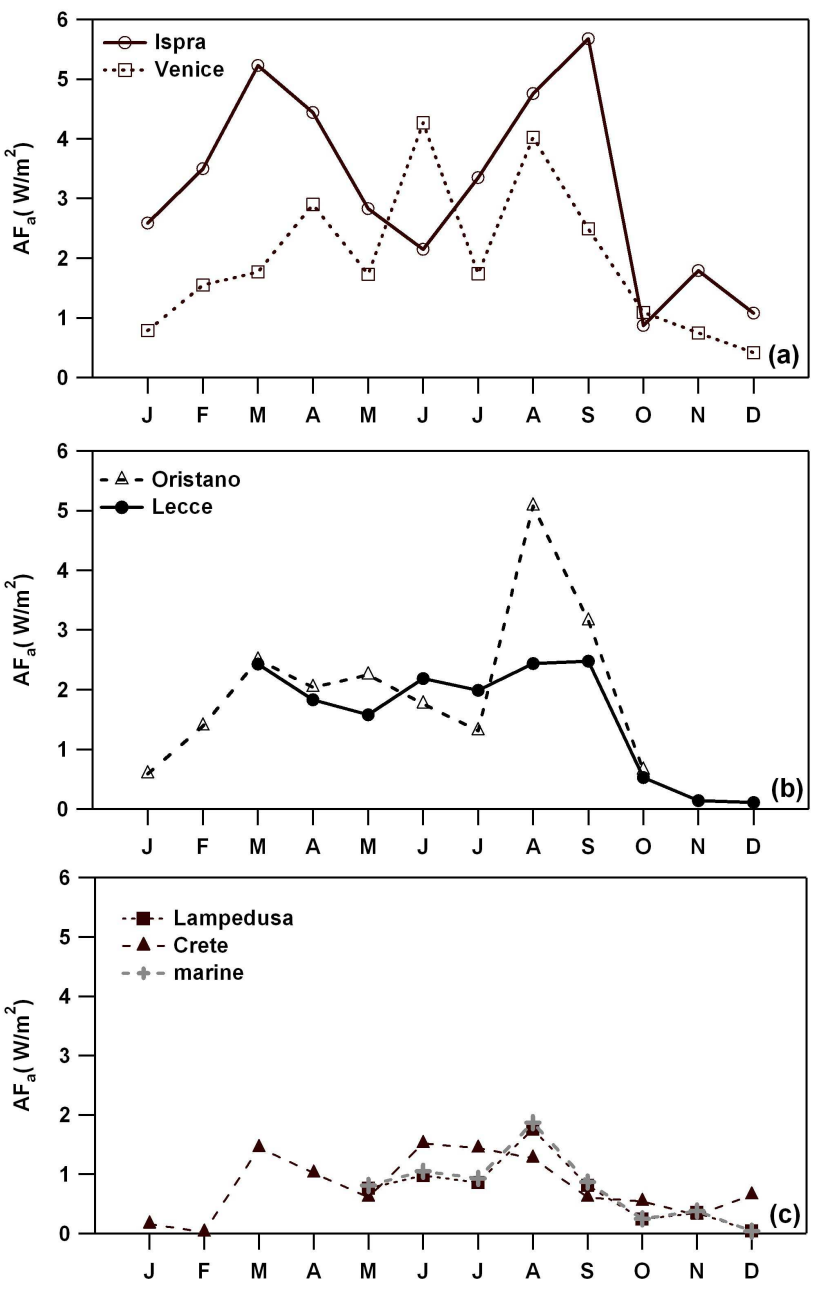

Fig. 12. Monthly evolution in 2003 of the solar $(0.3-4 \mu \mathrm{m})$ allsky atmospheric aerosol absorption by anthropogenic particles at (a) Ispra and Venice, (b) Oristano and Lecce, and (c) Lampedusa, Crete, and the marine area off the Lampedusa island.

Anthropogenic-aerosol forcing efficiencies $\left(\mathrm{AFE}_{\mathrm{a}}\right)$ at the ToA and surface, referring to $\mathrm{AOD}_{\mathrm{a}}$ at $550 \mathrm{~nm}$, are plotted in Figs. 13a-c and 14a-c, respectively, to infer the impact of factors such as aerosol absorption, size, and surface albedo. ToA- and sfc-AFE $\mathrm{a}$ values have a marked seasonality at all sites, characterized by smaller and larger absolute values on AW and SS, respectively. Hence, the variations with seasons of the aerosol optical and microphysical properties contribute to the seasonal trend of the $\mathrm{DRE}_{\mathrm{a}}$ observed at all sites both at the ToA and surface. Both the forcing efficiency dependence on Sun elevation (e.g. Russel et al., 1999) and the minimum cloud cover during summer also represent contributing factors to the $\mathrm{AFE}_{\mathrm{a}}$ annual cycle (Figs. 13a-c and $14 \mathrm{a}-\mathrm{c}$ ). Ispra represents the site where ToAand sfc-AFE $\mathrm{a}_{\mathrm{a}}$ values, which span the $-(3.1 \div 20.1) \mathrm{W} \mathrm{m}^{-2}$ and $-(18.9 \div 43.1) \mathrm{W} \mathrm{m}^{-2}$ range, respectively, are on average larger all year round. Hence, the same unit of $\mathrm{AOD}_{\mathrm{a}}$ 

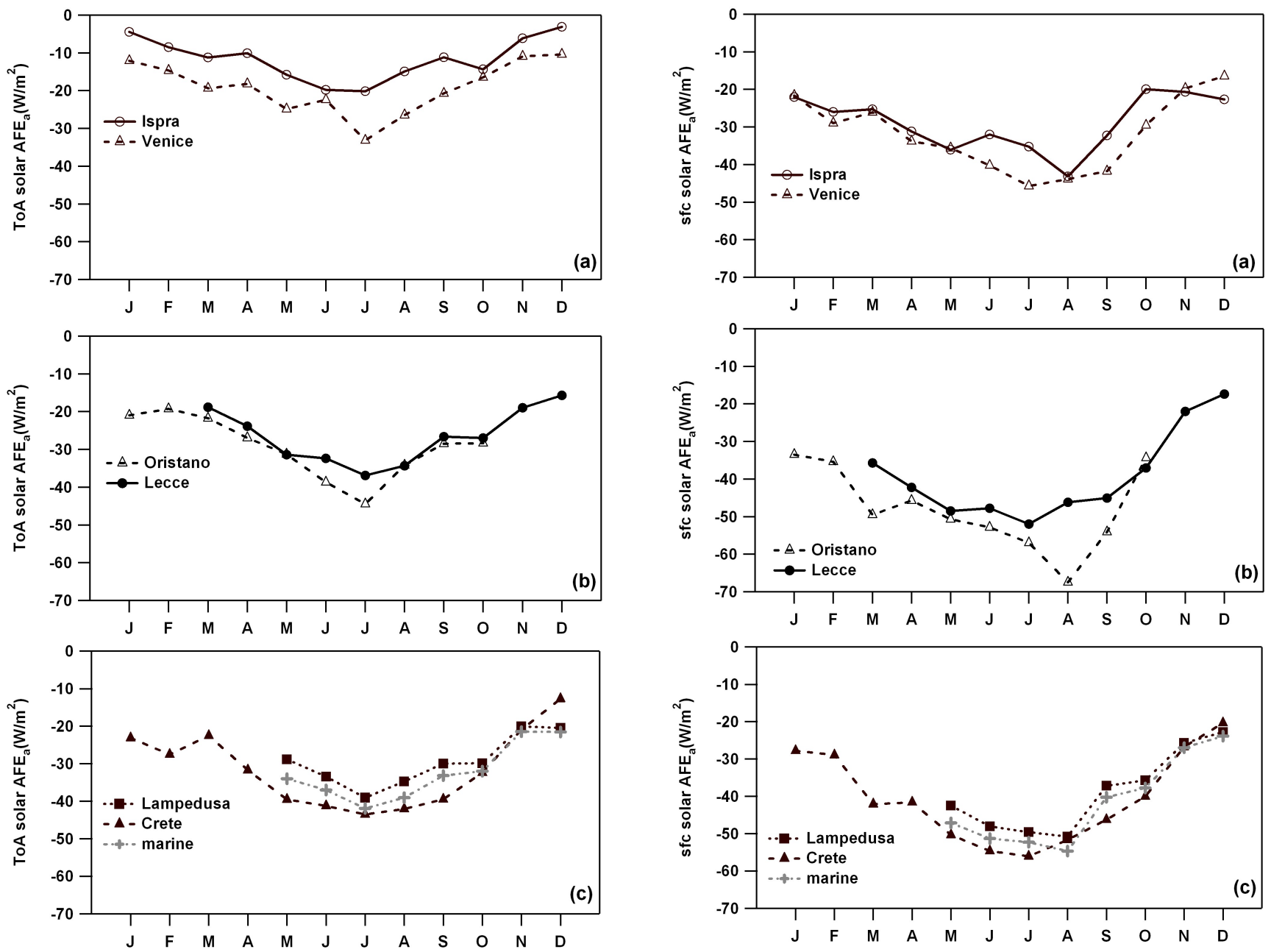

Fig. 13. Monthly evolution in 2003 of the solar $(0.3-4 \mu \mathrm{m})$ all-sky ToA atmospheric forcing efficiency by anthropogenic particles at (a) Ispra and Venice, (b) Oristano and Lecce, and (c) Lampedusa, Crete, and the marine area off the Lampedusa island.

produces at Ispra larger ToA- and sfc- $\mathrm{AFE}_{\mathrm{a}}$ values than those produced at the other sites. $\mathrm{AOD}_{\mathrm{a}}$ and $\mathrm{SSA}_{\mathrm{a}}$ values that on average take at Ispra larger and smaller values, respectively, are responsible for these last results. Oristano and Crete represent the sites where sfc- and $\mathrm{ToA}-\mathrm{AFE}_{\mathrm{a}}$ values reach higher negative values through all the year. $\mathrm{sfc} \mathrm{AFE}_{\mathrm{a}}$ values span the $-(33.5 \div 67.5) \mathrm{W} \mathrm{m}^{-2}$ range at Oristano, while ToA$\mathrm{AFE}_{\mathrm{a}}$ values span the $-(12.7 \div 43.5) \mathrm{W} \mathrm{m}^{-2}$ range at Crete. The ToA-AFE ${ }_{\mathrm{a}}$ decreases with the $\mathrm{SSA}_{\mathrm{a}}$ increase (e.g. Meloni et al., 2005), and Crete represents the site where on average $\mathrm{SSA}_{\mathrm{a}}$ values are larger. The $\mathrm{AFE}_{\mathrm{a}}$ data that are quite dependent on aerosol optical and microphysical properties and hence, on aerosol type, further more show that over the Mediterranean, the monthly-averaged anthropogenic-aerosol impact on climate is quite dependent on the site location.

Mean-values ( \pm 1 std. dev.) of monthly-means of all tested parameters have been calculated at each site and are given

in Table 4a in addition to SS- and AW-mean-values, to facilitate comparison between different sites. At the ToA the monthly average $\mathrm{DRE}_{\mathrm{a}}$ is $\cong-(4 \pm 1) \mathrm{W} \mathrm{m}^{-2}$ during springsummer (SS, April-September) and $\cong-(2 \pm 1) \mathrm{W} \mathrm{m}^{-2}$ during autumn-winter (AW, October-March) at the polluted sites. In contrast, it is $-(3.0 \pm 0.9) \mathrm{W} \mathrm{m}^{-2}$ and $-(0.9 \pm 0.5) \mathrm{W} \mathrm{m}^{-2}$ on SS and AW, respectively at Lampedusa. At the surface the monthly average $D_{R E}$ varies between the most and the least polluted site between $-(7.2 \pm 2.2) \mathrm{W} \mathrm{m}^{-2}$ and $-(3.9 \pm 1.2) \mathrm{W} \mathrm{m}^{-2}$ during $\mathrm{SS}$, and between $-(4.1 \pm 2.9) \mathrm{W} \mathrm{m}^{-2}$ and $-(1.1 \pm 0.7) \mathrm{W} \mathrm{m}^{-2}$ during $\mathrm{AW}$. It is worth observing for nearly all investigated parameters of Table 4a, that the differences between meanvalues of different sites are lower than \pm 1 std. dev., even if monthly-mean-values significantly vary from site to site. The high spatial and temporal variability of the anthropogenic aerosol load over the Mediterranean is probably responsible 
for these last results. ToA- and sfc-DRE $E_{a}$ yearly-mean values, which have been calculated by averaging all available monthly-means, respectively, are reported in Table 5. We believe that Table 5 data can provide a 1st-order estimate of the anthropogenic-aerosol impact on the radiative energybalance of Central Mediterranean land and coastal sites for the 2003-year. Table 5 data appear to be in satisfactory accordance with corresponding values provided by Chung et al. (2005) for the Mediterranean basin, at least within \pm 1 std. dev. However, they are larger than corresponding values retrieved by several chemical transport models coupled to general circulation models (e.g. Schulz et al., 2006; Stier et al., 2007), which are not based on experimental data.

Finally, it is worth noting that the ToA- and sfc-DRE yearly-mean values of Table 5 are significantly larger than corresponding global-yearly-mean values provided by several models (e.g. Chung et al., 2005). This last observation indicates that the energy-balance of the Mediterranean is quite affected by pollution and as a consequence, the Mediterranean can be one of the most responsive regions to climate changes in accordance to Giorgi (2006). We mention that IPCC (2007) provides a summary of the principal atmospheric components responsible of DREs, which can be rather useful to compare the results of this paper with those provided by other authors both for the aerosol and other atmospheric components.

4.2 Anthropogenic ToA and surface DREs at infrared wavelengths $(4-200 \mu \mathrm{m})$

It is worth noting that we have assumed that the anthropogenic aerosol is $<1 \mu \mathrm{m}$ in maximum dimension, as a consequence we cannot expect significant radiative anthropogenic-aerosol effects at infrared wavelengths. Figure 15a-c and Fig. 16a-c show the monthly evolution of the all-sky IR-DRE by anthropogenic aerosols at the ToA and at the surface (sfc), respectively. The IR- DRE $\mathrm{a}_{\mathrm{a}}$ is positive both at the ToA and surface since aerosols produce planetary and surface warming through interaction with IR radiation. However, as expected, it is small compared to the solar DRE pecially at the ToA. The seasonal trend of the infrared ToA$\mathrm{DRE}_{\mathrm{a}}$ that reaches higher values on $\mathrm{SS}$, is similar at all sites. Peak values that are reached on summer are of $\sim 0.1 \mathrm{~W} \mathrm{~m}^{-2}$ at most of the sites, while a peak value of $0.04 \mathrm{~W} \mathrm{~m}^{-2}$ is reached at Lampedusa. Infrared sfc-DRE $\mathrm{a}_{\mathrm{a}}$ values that on summer reach peak values close to $0.35 \mathrm{~W} \mathrm{~m}^{-2}$ at most of the sites are significantly larger than ToA-DRE $E_{a}$ values and offset 3-6\% of the (negative) solar DRE $\mathrm{a}_{\mathrm{a}}$. It is worth observing that sfc-DRE $E_{a}$ values vary within the $(0.0 \div 0.2) \mathrm{W} \mathrm{m}^{-2}$ range at Lampedusa that represents the site where sfc-DRE values are smaller all year round.

IR-anthropogenic-aerosol forcing efficiencies $\left(\mathrm{AFE}_{\mathrm{a}}\right)$ at the ToA and surface and referring to $\mathrm{AOD}_{\mathrm{a}}$ at $550 \mathrm{~nm}$ have also been calculated. Mean-values ( \pm 1 std. dev.) of monthlymeans of all tested parameters are given in Table $4 \mathrm{~b}$ for each
Table 5. Yearly-mean values of the $\mathrm{DRE}_{\mathrm{a}}$ and of the $\mathrm{AFE}_{\mathrm{a}}$ at solar and IR wavelengths for Central Mediterranean land and coastal sites.

\begin{tabular}{|c|c|c|c|c|}
\hline \multicolumn{5}{|c|}{ Solar wavelength $\left(\mathrm{W} \mathrm{m}^{-2}\right)$} \\
\hline & $\overline{\mathrm{DRE}}_{\mathrm{a}}^{\mathrm{ToA}}$ & $\overline{\mathrm{DRE}}_{\mathrm{a}}^{\mathrm{sfc}}$ & $\overline{\mathrm{AFE}}_{\mathrm{a}}^{\mathrm{ToA}}$ & $\overline{\mathrm{AFE}}_{\mathrm{a}}^{\mathrm{sfc}}$ \\
\hline This paper & $-(3 \pm 2)$ & $-(5 \pm 3)$ & $-(24 \pm 10)$ & $-(38 \pm 12)$ \\
\hline Chung et al., 2005 & $-(3 \pm 1)$ & $-(9 \pm 6)$ & & \\
\hline \multicolumn{5}{|c|}{ IR wavelength $\left(\mathrm{W} \mathrm{m}^{-2}\right)$} \\
\hline & $\begin{array}{l}\overline{\mathrm{DRE}}_{\mathrm{a}}^{\mathrm{ToA}} \\
0.03 \pm 0.03\end{array}$ & $\begin{array}{l}\overline{\mathrm{DRE}}_{\mathrm{a}}^{\mathrm{sfc}} \\
0.17 \pm 0.08\end{array}$ & $\begin{array}{l}\overline{\mathrm{AFE}}_{\mathrm{a}}^{\mathrm{ToA}} \\
0.22 \pm 0.18\end{array}$ & $\begin{array}{l}\overline{\mathrm{AFE}}_{\mathrm{a}}^{\mathrm{sfc}} \\
1.3 \pm 0.4\end{array}$ \\
\hline
\end{tabular}

site. Tested parameter mean-values referring to different sites have then been averaged and are reported in Table 5 to provide a 1st order estimate of the annual anthropogenic-aerosol impact on the long-wave radiative energy-balance of coastal and land sites of the Central Mediterranean for the 2003 year. The IR effect of tropospheric aerosols is often neglected being small compared to the solar effect and as a consequence not many data are available in literature. Recently, Stier et al. (2007) have used the comprehensive aerosol-climate model ECHAM5-HAM to globally calculate for the 2000 year, the long-wave anthropogenic aerosol ToA DRE and atmospheric forcing. According to Stier et al. (2007) ToA$\mathrm{DRE}_{\mathrm{a}}$ and $\mathrm{AF}_{\mathrm{a}}$ values for the 2000-year, vary within the $(0.02 \div 0.1) \mathrm{W} \mathrm{m}^{-2}$ and $(0.1 \div 0.5) \mathrm{W} \mathrm{m}^{-2}$ range, respectively over the Mediterranean basin. These last results even if refer to a different year than that analyzed in this paper, appear to be in satisfactory accordance with the data of Table 5 .

\section{Sensitivity studies}

The role of few selected aerosol properties on the anthropogenic aerosol DRE at solar wavelengths is investigated in this section. In particular, the $\mathrm{DRE}_{\mathrm{a}}$ sensitivity to the anthropogenic aerosol fraction $(f)$ and to the imaginary refractive index $(k)$ of the anthropogenic aerosol component is investigated. We believe that $f$ and $k$ values are probably affected by larger uncertainties with respect to the other input parameters. The $\mathrm{DRE}_{\mathrm{a}}$ sensitivity to the surface albedo is also investigated in this section. Results of the sensitivity tests are given in terms of percentage changes $(\Delta F \%)$ of the aerosol $\mathrm{DRE}_{\mathrm{a}}$, where:

$\Delta F \%=\left(\frac{F-F_{\text {ref }}}{F_{\text {ref }}}\right) \cdot 100$

$F_{\text {ref, }}$ is the $\mathrm{DRE}_{\mathrm{a}}$ of the reference case and $F$ represents the $\mathrm{DRE}_{\mathrm{a}}$ obtained after varying a particular aerosol property. 

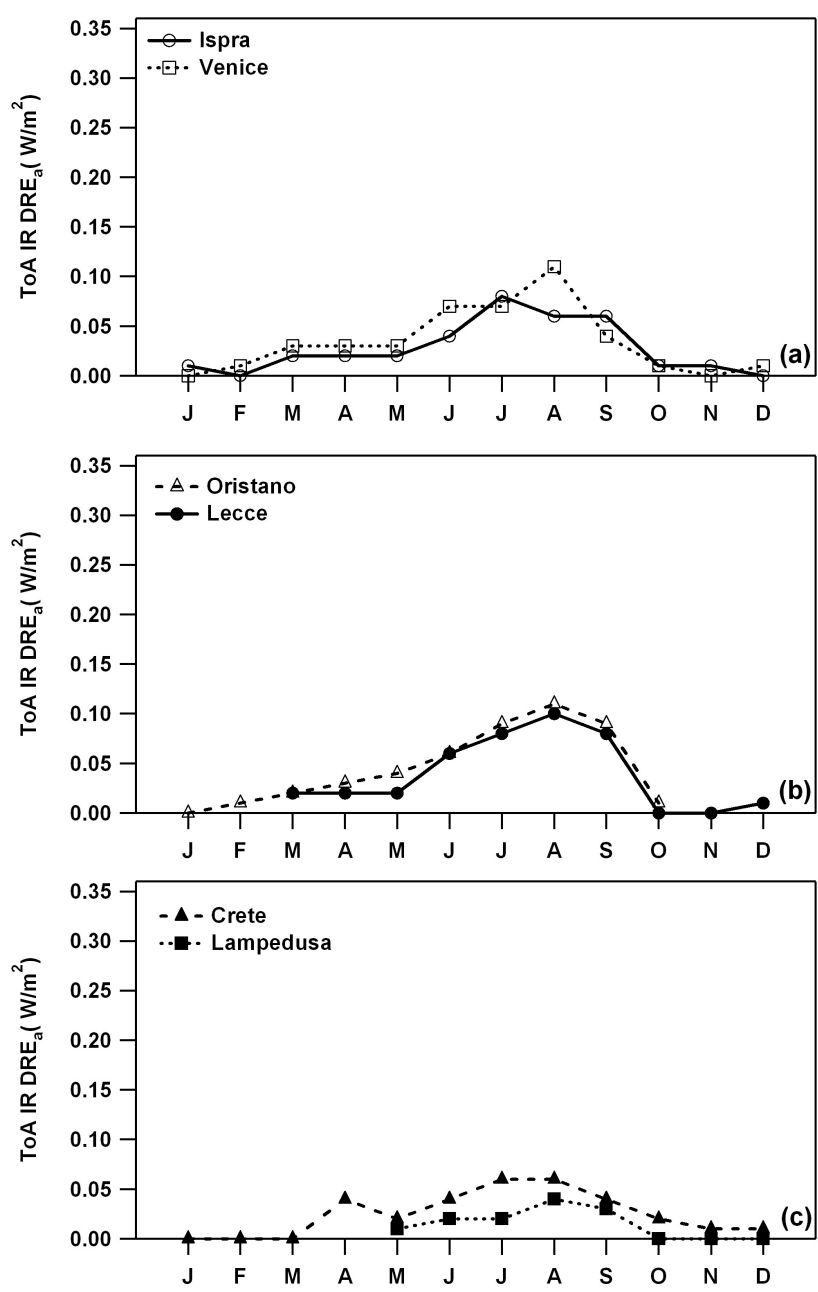

Fig. 15. Monthly evolution in 2003 of the infrared (4-200 $\mu \mathrm{m})$ allsky ToA-DRE by anthropogenic particles at (a) Ispra and Venice, (b) Oristano and Lecce, and (c) Lampedusa and Crete.

\subsection{Anthropogenic aerosol DRE sensitivity to $f$ values}

The number concentration of anthropogenic-origin particles has been determined in this study by using model-based $f$ values (Schulz et al., 2006), in accordance with Eq. (1). The role of the model-based $f$ values on the anthropogenic aerosol DRE is investigated by replacing at each site, modelbased $f$ values with the corresponding values provided by the relationship

$f^{+,-}=f \pm 0.1 f$

The factor 0.1 in Eq. (3) has been established in order not to get $f$ values larger than one. $f^{+}$is close to 1 on winter months at Ispra. This last result indicates that all finemode particles are of anthropogenic origin on winter at Ispra. Table 6 provides for all sites absolute change mean values \pm 1 std. dev. of the anthropogenic aerosol optical depth
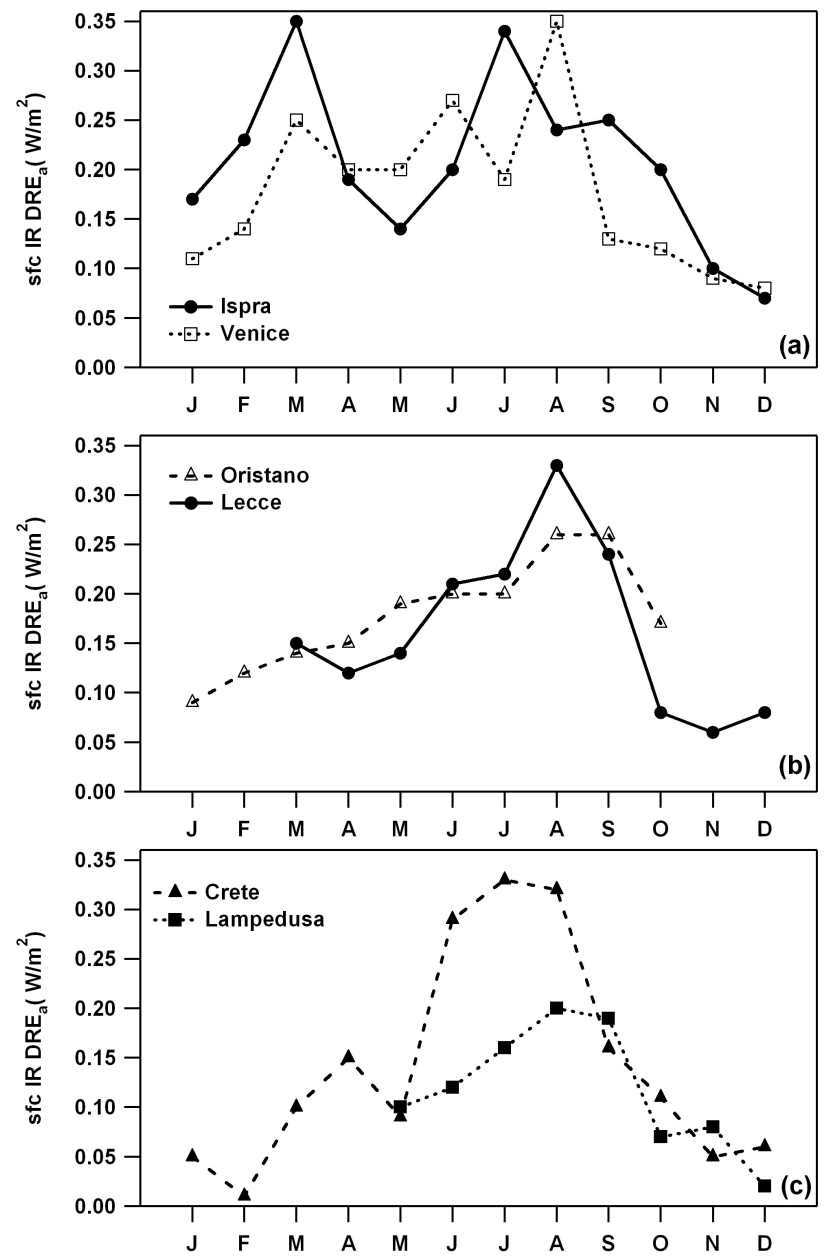

Fig. 16. Monthly evolution in 2003 of the infrared (4-200 $\mu \mathrm{m})$ allsky sfc-DRE by anthropogenic particles at (a) Ispra and Venice, (b) Oristano and Lecce, and (c) Lampedusa and Crete.

$\left(\left|\Delta^{+,-} \mathrm{AOD}_{\mathrm{a}}\right|\right)$ determined by the use of $f^{+}$or $f^{-}$values. We observe that $\left|\Delta^{+,-} \mathrm{AOD}_{\mathrm{a}}\right|$ values are lower than the AOD accuracy $( \pm 0.01)$ at all sites with the exception of Ispra and Venice. Mean values of absolute change percentages \pm 1 std. dev. of the anthropogenic aerosol DRE at the ToA and surface, respectively are also given in Table 6, which shows that absolute mean-percentages are $\leq 10 \%$ at all sites.

\subsection{Anthropogenic aerosol DRE sensitivity to the imagi- nary refractive index values}

In accordance with the discussion of Sect. 3.3, refractive index values retrieved from AERONET sun/sky photometer measurements for the whole aerosol load have also been ascribed to the anthropogenic aerosol component. In order to investigate the effects of this last assumption on the DREs of anthropogenic particles, the sensitivity of $\mathrm{DRE}_{\mathrm{a}}$ values to imaginary refractive index values is analyzed in this section. To this end, imaginary refractive index values 
Table 6. Absolute changes of the $\mathrm{AOD}_{\mathrm{a}} \pm 1$ std. dev. and absolute change-percentages \pm 1 std. dev. of the solar $\mathrm{DRE}_{\mathrm{a}}$ at the ToA and at the surface ( $\mathrm{sfc}$ ) determined by the replacement of the $f$ values of Table 2 with the ones provided by Eq. (3).

\begin{tabular}{lccc}
\hline & $\left|\Delta^{+,-} \mathrm{AOD}_{\mathrm{a}}\right|$ & $\left|\Delta^{+,-} \mathrm{DRE}_{\mathrm{a}}^{\mathrm{ToA}}\right|$ & $\left|\Delta^{+,-} \mathrm{DRE}_{\mathrm{a}}^{\mathrm{sfc}}\right|$ \\
$\%$
\end{tabular}

(k) retrieved from AERONET sun/sky photometer measurements have been replaced at all sites with the values provided by the relationship

$k^{+,-}=k \pm 0.5 k$

According to Dubovik et al. (2000) uncertainties on $k$ values are of $50 \%$ at AOD $(440 \mathrm{~nm}) \geq 0.2$. Table 7 provides for all sites the absolute change mean-values \pm 1 std. dev. of the anthropogenic SSA $\left(\left|\Delta^{+,-} \mathrm{SSA}_{\mathrm{a}}\right|\right)$ determined by the use of $k^{+}$or $k^{-}$values. We observe from Table 7 that absolute change mean-values $\left|\Delta^{+,-} \mathrm{SSA}_{\mathrm{a}}\right|$ are comparable to the theoretical accuracy of its retrieval (Dubovik et al., 2000). The effects of $k^{+}$or $k^{-}$values on $\mathrm{AOD}_{\mathrm{a}}$ and $g_{a}$ values are negligible. Table 7 also provides for all sites mean values of absolute change-percentages \pm 1 std. dev. of the anthropogenic aerosol DRE at the ToA and surface, respectively. We observe from Table 7 that the absolute mean-percentage values are larger at Ispra, Venice, and Oristano. However, it is worth noting that the rather high mean-percentage value $\left|\Delta^{+,-} \mathrm{DRE}_{\mathrm{a}}^{\mathrm{ToA}}\right|=(40 \pm 30) \%$ of Ispra, is mainly determined by the rather low values of the AW ToA- DRE that at Ispra reaches values close to zero on December (Fig. 10a). Lecce, Lampedusa, and Crete that are the sites less affected by anthropogenic particles, are characterized by $\left|\Delta^{+,-}{ }^{-} E_{a}\right| \leq 10 \%$ both at the surface and at the ToA.

5.3 Anthropogenic aerosol DRE sensitivity to surface albedo values

The DRE by anthropogenic particles is additionally computed in this section using open sea surface albedo values. This study allows investigating the $\mathrm{DRE}_{\mathrm{a}}$ sensitivity to surface albedo values and in particular, can allow getting a first order estimate on how much the $\mathrm{DRE}_{\mathrm{a}}$ computed in this paper for coastal sites, differs from that of open-sea areas off the coastal sites. To this end, at first we have retrieved by the MODIS MOD43B3 products the monthly-average surfacealbedo values of a marine area $\left(34.50^{\circ} \mathrm{N}, 14.50^{\circ} \mathrm{E}\right)$ off the Lampedusa island (Fig. 1). Marine surface albedo values
Table 7. Absolute changes of $\mathrm{SSA}_{\mathrm{a}} \pm 1$ std. dev. values and absolute change-percentages \pm 1 std. dev. of the solar $\mathrm{DRE}_{\mathrm{a}}$ at the ToA and at the surface ( $\mathrm{sfc}$ ) determined by the replacement of the $k$-AERONET values with the ones provided by Eq. (4).

\begin{tabular}{lccc}
\hline & $\left|\Delta^{+,-} \mathrm{SSA}_{\mathrm{a}}\right|$ & $\left|\Delta^{+,-} \mathrm{DRE}_{\mathrm{a}}^{\mathrm{ToA}}\right|$ & $\left|\Delta^{+,-} \mathrm{DRE}_{\mathrm{a}}^{\mathrm{sfc}}\right|$ \\
$\%$
\end{tabular}

are plotted by grey crosses in Fig. 2. The comparison of marine- and Lampedusa-surface-albedo values for the visible $(0.3-0.7 \mu \mathrm{m})$ spectral range (Fig. 2a), reveals that marinesurface-albedo monthly values are from $50 \%$ to $65 \%$ smaller than corresponding Lampedusa-surface-albedo monthly values, except on January: the marine-surface-albedo monthly value is $26 \%$ smaller than that of Lampedusa on January. The comparison of marine- and Lampedusa-surface-albedo values for the infrared $(0.7-5.0 \mu \mathrm{m})$ spectral range (Fig. 2b), reveals that marine-surface-albedo monthly values are from $26 \%$ to $32 \%$ smaller than corresponding Lampedusa-surfacealbedo monthly values, except on January: the marinesurface-albedo monthly value is $16 \%$ smaller than that of Lampedusa on January. Figure 2 allows also inferring that the differences between Crete- and marine-surface-albedo monthly values are less than $35 \%$. Then, we have assumed that Lampedusa aerosol properties could also be extrapolated off-shore and in particular, to the marine site marked in Fig. 1, in order to calculate the $\mathrm{DRE}_{\mathrm{a}}$. The monthly evolution, at the marine area $\left(34.50^{\circ} \mathrm{N}, 14.50^{\circ} \mathrm{E}\right)$, of the all-sky DRE by anthropogenic aerosols at the ToA and at the surface (sfc) is plotted by crosses in Figs. 10c and 11c, respectively. The switch to smaller surface albedo values increases in absolute value the solar DRE $\mathrm{a}$ at the TOA and at the surface, as illustrated in Figs. 10c and 11c, respectively: lower surface albedo values increase the aerosol's potential to change the upwelling radiation and thus net fluxes. In particular, at the marine area, ToA-DRE $\mathrm{a}_{\mathrm{a}}$ monthly values are in absolute value from $14 \%$ to $23 \%$ larger than corresponding LampedusaToA- $\mathrm{DRE}_{\mathrm{a}}$ monthly values. Conversely, sfc-DRE $\mathrm{a}_{\mathrm{a}}$ monthly values at the marine area are in absolute value from $16 \%$ to $31 \%$ larger than Lampedusa-ToA-DRE $\mathrm{a}_{\mathrm{a}}$ monthly values. These last results that are in accordance with previous studies (e.g. Tafuro et al., 2007), indicate that the ToA- and sfccooling effect of aerosols increases off-shore if one assume that coastal-site aerosol properties can be extrapolated offshore. Hence, we believe that the inclusion in this paper of results on off-shore (or open Sea) DREs by anthropogenic particles would have further increased in absolute value, the mean $\mathrm{DRE}_{\mathrm{a}}$ values reported in Table 5. 


\section{Conclusion and summary}

This paper has provided significant results on the seasonal dependence of the DRE by anthropogenic particles at Mediterranean land sites differently affected by anthropogenic pollution. This makes this paper unique. Most available studies on the aerosol DRE over the Mediterranean refer to dedicated campaigns during special pollution events (e.g. Sahara dust outbreaks) and mainly account for the solar DRE determined by all (natural+anthropogenic) particles. Here, in contrast, monthly evolutions of the anthropogenic aerosol impact on the solar and IR direct radiative forcing under all-sky conditions have been presented for different sites. In addition, paper results have allowed getting for the 2003 year, a 1st order estimate of the yearly-mean value of the ToA- and sfc-DRE by anthropogenic particles over land and coastal sites of the Mediterranean basin.

Aerosol optical and microphysical properties of AERONET sun/sky photometer data at six Mediterranean sites (Ispra, Venice, Oristano, Lecce, Lampedusa, and Crete) of the year 2003 (the warmest in recent years), have been applied in a radiative transfer code to simulate monthly mean values of the direct radiative effect (DRE) by anthropogenic particles. The use of observation-based aerosol properties also represents a peculiarity of the paper.

A detailed analysis of the AERONET aerosol properties (AOD, $\eta$, SSA, and g) at each selected site has been performed to better understand the dependence of the aerosol DRE on site location and hence on corresponding anthropogenic aerosol properties. It has been shown that the selected sites are differently affected by natural and anthropogenic particles. Ispra and Venice that are the site with on average larger aerosol loads all year round, also are the sites more affected by anthropogenic particles. In contrast, Lampedusa and Crete are the sites less affected by anthropogenic particles and also characterized by smaller AOD values. The mean percentage of the $\mathrm{AOD}_{\mathrm{a}} / \mathrm{AOD}$ ratio that is larger of $70 \%$ at Ispra and Venice is equal to $40 \%$ at Lampedusa and Crete. Last two sites are also characterized by larger SSA values. A marked seasonality of the aerosol properties dependent on site location has also been observed at all sites.

We have found that calculated monthly-means of the solar sfc- and ToA-DRE ${ }_{\mathrm{a}}$ are negative all year round and are also characterized by larger negative values on SS at all sites with the exception of Ispra. Then, it has been shown that anthropogenic particles produce over the central Mediterranean a significant cooling effect both at the surface and at the ToA, and that the cooling effect at the surface is larger than that associated to the ToA for the presence of absorbing aerosols. sfc-DRE $_{a}$ values are up to 7 times larger than ToA-DRE values at Ispra, since the anthropogenic aerosol is much more absorbing than at other sites. In contrast, mean sfc-DRE $\mathrm{a}_{\mathrm{a}}$ values are 1.3 times larger than the ToA-DRE ${ }_{a}$ values at Lampedusa and Crete. As a consequence, the AF by anthropogenic particles reaches a value of $5 \mathrm{~W} \mathrm{~m}^{-2}$ at Ispra, while it is always less than $2 \mathrm{~W} \mathrm{~m}^{-2}$ at Lampedusa and Crete.

Atmospheric forcing efficiency calculations have also provided larger negative values at the surface than at the ToA for all sites. In particular, we have found that the DRE by anthropogenic particles per unit optical depth reaches larger (smaller) values at Ispra (Oristano) both at the ToA and surface. $\mathrm{AFE}_{\mathrm{a}}$ values are also characterized at all sites by a marked seasonality with larger values on SS, as a consequence of the seasonality of the anthropogenic particle properties.

The average of monthly-means has revealed that sfc- and ToA-DRE $E_{a}$ averaged-values vary from site to site. However, the differences between averaged-values of different sites are smaller than the associated standard deviation. These last results may indicate that the yearly-DRE by anthropogenic particles is not very sensitive to the site location over Central Mediterranean land and coastal sites.

We have also observed that compared to the solar $\mathrm{DRE}_{\mathrm{a}}$, the IR DRE by anthropogenic particles is significantly smaller in magnitude and positive. In particular, the IR ToA$\mathrm{DRE}_{\mathrm{a}}$ is $\leq 0.11 \mathrm{~W} \mathrm{~m}^{-2}$ at all sites, while at the surface the IR DRE $\mathrm{a}$ varies within the $0.01 \div 0.35 \mathrm{~W} \mathrm{~m}^{-2}$ range, offsetting few percent of the negative solar $\mathrm{DRE}_{\mathrm{a}}$. The average of monthly-means has also revealed that the differences between IR sfc- and ToA-DRE $E_{a}$ averaged-values of different sites are smaller than the associated standard deviations.

Finally, all available monthly-means have been used to calculate the yearly-mean value of the $\mathrm{DRE}_{\mathrm{a}}$ at the ToA $\left(\overline{\mathrm{DRE}}_{\mathrm{a}}^{\mathrm{ToA}}\right)$ and at the surface $\left(\overline{\mathrm{DRE}}_{\mathrm{a}}^{\mathrm{sfc}}\right)$, and of the $\mathrm{AFE}_{\mathrm{a}}$ at the ToA $\left(\overline{\mathrm{AFE}}_{\mathrm{a}}^{\mathrm{ToA}}\right)$ and at the surface $\left(\overline{\mathrm{AFE}}_{\mathrm{a}}^{\mathrm{sfc}}\right)$, at solar and infrared wavelengths. It has been found that the yearly-mean value of the solar DRE by anthropogenic particles is $-(3 \pm 2)$ and $-(5 \pm 3) \mathrm{W} \mathrm{m}^{-2}$ at the ToA and surface, respectively. The above data, which provides a 1st order estimate of the ToA- and sfc-DRE $\mathrm{a}_{\mathrm{a}}$ of Mediterranean land and coastal sites for the 2003 year, are significantly larger than corresponding global-yearly-mean values provided by several models. Hence, the results of this paper show that the energy-balance of the Mediterranean is quite affected by pollution and as a consequence, that the Mediterranean can be one of the most responsive regions to climate changes.

In sensitivity studies the relatively weak impact of imaginary refractive index and $f$ changes on the mean optical properties of anthropogenic particles has been demonstrated. In fact, changes of $k$ and $f$ values by \pm 50 and $\pm 10 \%$, respectively, with respect to corresponding reference values have determined on average changes of the ToA- and sfc-DRE $E_{a}$ values lower than $10 \%$ at most of the sites. Finally, the study on the $\mathrm{DRE}_{\mathrm{a}}$ sensitivity to surface albedo values has revealed that the ToA- and sfc-cooling effect of aerosols increases offshore if one assumes that coastal-site aerosol properties can be extrapolated off-shore. 
Acknowledgements. This work was supported by Ministero dell' Istruzione dell'Università e della Ricerca of Italy, (Programma di Ricerca di Interesse Nazionale 2006. Prot. 2006027825), by the European Project EARLINET-ASOS (2006-2011, contract no. 025991), by Progetto FISR AEROCLOUDS and by Centro EuroMediterraneo per i Cambiamenti Climatici (CMCC). The authors kindly acknowledge Principal Investigators of the AERONET stations of Ispra, Venice, Oristano, Lampedusa, and Crete.

Edited by: N. Mihalopoulos

\section{References}

Andreae, T. W., Andreae, M. O., Ichoku, C., Maenhaut, W., Cafmeyer, J., Karnieli, A., and Orlovsky, L.: Light scattering by dust and anthropogenic aerosol at a remote site in the Negev desert, Israel, J. Geophys. Res., 107(D2), 4008, doi:10.1029/2001JD900252, 2002.

Bellouin, N., Boucher, O., Haywood, J., and Reddy, M. S.: Global estimate of aerosol direct radiative forcing from satellite measurements, Nature, 438, 1138-1141, 2005.

Chin, M., Ginoux, P., Kinne, S., Torres, O., Holben, B. N., Duncan, B. N., Martin, R. V., Logan, J. A., Higurashi, A., and Nakajima, T.: Troposheric aerosol optical thickness from the GOCART model and comparison with satellite and sun photometer measurements, J. Atmos. Sci., 59, 461-483, 2002.

Chung, C. E., Ramanathan, V., Kim, D., and Podgorny, I. A.: Global anthropogenic aerosol direct forcing derived from satellite and groundbased observations, J. Geophys. Res., 110, D24207, doi:10.1029/2005JD006356, 2005.

Collins, W. J., Derwent, R. G., Johnson, C. E., and Stevenson, D. S.: The oxidation of organic compounds in the troposphere and their global warming potentials, Clim. Change, 52, 453-479, 2002.

Dentener, F., Kinne, S., Bond, T., Boucher, O., Cofala, J., Generoso, S., Ginoux, P., Gong, S., Hoelzemann, J. J., Ito, A., Marelli, L., Penner, J. E., Putaud, J.-E., Textor, C., Schulz, M., van der Werf, G. R., and Wilson, J.: Emissions of primary aerosol and precursor gases in the years 2000 and 1750 prescribed data-sets for Aerocom, Atmos. Chem. Phys., 6, 4321-4344, 2006, http://www.atmos-chem-phys.net/6/4321/2006/.

Dubovik, O. and King, M. D.: A flexible inversion algorithm for retrieval of aerosol optical properties from Sun and sky radiance measurements, J. Geophys. Res., 105, 20 673-20 696, 2000.

Dubovik, O., Smirnov, A., Holben, B. N., King, M. D., Kaufman, Y. J., Eck, T. F, and Slutsker, I: Accuracy assessments of aerosol optical properties retrieved from Aerosol Robotic Network (AERONET) Sun and sky radiance measurements, J. Geophys. Res, 105(D8), 9791-9806, 2000.

Dubovik, O., Holben, B. N., Lapyonok, T., Sinyuk, A., Mishchenko, M. I., Yang, P., and Slutsker, I.: Non-spherical aerosol retrieval method employing light scattering by spheroids, Geophys. Res. Lett., 29(10), 541-544, 2002.

Dubovik, O., Sinyuk, A., Lapyonok, T., Holben, B. N., Mishchenko, M., Yang, P., Eck, T. F., Volten, H., Muñoz, O., Veihelmann, B., Van Der Zande, W. J., Leon, J. F., Sorokin, M., and Slutsker, I.: Application of spheroid models to account for aerosol particle nonsphericity in remote sensing of desert dust, J. Geophys. Res., 111, D11208, doi:10.1029/2005JD006619, 2006.
Fotiadi, A., Hatzianastassiou, N., Drakakis, E., Matsoukas, C., Pavlakis, K. G., Hatzidimitriou, D., Gerasopoulos, E., Mihalopoulos, N., and Vardavas, I.: Aerosol physical and optical properties in the Eastern Mediterranean Basin, Crete, from Aerosol Robotic Network data, Atmos. Chem. Phys., 6, 53995413, 2006, http://www.atmos-chem-phys.net/6/5399/2006/.

Giorgi, F., Bi, X. Q., and Qian, Y.: Direct radiative forcing and regional climatic effects of anthropogenic aerosols over East Asia: A regional coupled climate-chemistry/aerosol model study, J. Geophys. Res., 107, 4439, doi:10.1029/2001JD001066, 2002.

Giorgi, F.: Climate change hot-spots, J. Geophys. Res., 33, L08707, doi:10.1029/2006GL025734, 2006.

Guibert, S., Matthias, V., Schulz, M., Bösenberg, J., Eixmann, R., Mattis, I., Pappalardo, G., Perrone, M. R. , Spinelli, N., and Vaughan, G.: The vertical distribution of aerosol over Europe synthesis of one year of EARLINET aerosol lidar measurements and aerosol transport modeling with LMDzT-INCA, Atmos. Environ., 39, 2933-2943, 2005.

Haywood, J. and Boucher, O.: Estimates of the direct and indirect radiative forcing due to tropospheric aerosols: a review, Rev. Geophys., 38, 4, 513-543, 2000.

Holben, B. N., Eck, T. F., Slutsker, I., Tanré, D., Buis, J. P., Setzer, A., Vermote, E., Reagan, J. A., Kaufman, Y., Nakajima, T., Lavenu, F., Jankowiak, I., and Smirnov, A.: AERONET - A federated instrument network and data archive for aerosol characterization, Remote Sens. Environ., 6, 1-16, 1998.

Holben, B. N., Tanré, D., Smirnov, A., Eck, T. F., Slutsker, I., Abuhassan, N., Newcomb, W. W., Shafer, J., Chatenet, B., Lavenue, F., Kaufman, Y. J., Vande Castel, J., Setzer, A., Markham, B., Clark, D., Frouin, R., Halthore, R., Karnieli, A., O’Neill, N. T., Pietras, C., Pinker, R. T., Voss, K., and Zibordi, G.: An emerging ground-based aerosol climatology: Aerosol optical depth from AERONET, J. Geophys. Res, 106, 12 067-12 097, 2001.

Intergovermental Panel on Climate Change (IPCC): Climate change 2007, The Physical Science Basis - Summary for Policymakers, http://www.ipcc.ch/ipccreports/ar4-wg1.htm, 2007.

Kaufman, Y. J., Smirnov, A., Holben, B. N., and Dubovik, O.: Baseline maritime aerosol: methodology to derive the optical thickness and scattering properties, J. Geophys. Res. Lett., 28, 17, 3251-3254, 2001

Kaufman, Y. J., Tanré, D., and Boucher, O.: A satellite view of aerosols in the climate system, Nature, 419, 215-223, 2002.

Kaufman, Y. J., Boucher, O., Tanré, D., Chin, M., Remer, L. A., and Takemura, T.: Aerosol anthropogenic component estimated from satellite data, Geophys. Res. Lett., 32, L17804, doi:10.1029/2005GL023125, 2005.

King, M. D., Kaufman, Y. J., Menzel, W. P., and Tanré, D.: Remote Sensing of Cloud, Aerosol, and Water Vapor Properties from the Moderate Resolution Imaging Spectrometer (MODIS), IEEE T. Geosci. Remote, 30, 1-27, 1992.

Kirkevåg, A. and Iversen, T.: Global direct radiative forcing by process-parameterized aerosol optical properties, J. Geophys. Res.-Atmos., 107(D20), 4433, doi:10.1029/2001JD000886, 2002.

Lelieveld, J., Berresheim, H., Borrman, S., Crutzen, P. J., Dentener, F. J., Fischer, H., Feichter, J., Flatau, P. J., Heland, J., Holzinger, R., Korrmann, R., Lawrence, M. G., Levin, Z., Markowicz, K. M., Mihalopoulos, N., Minikin, A., Ramanathan, V., De Reus, 
M., Roelofs, G. J., Scheeren, H. A, Sciare, J., Schultz, M., Siegmund, P., Steil, B., Stephanou, E. G., Stier, P., Traub, M., Warneke, C., Williams, J., and Ziereis, H.: Global air pollution crossroads over the Mediterranean, Science, 298, 794-799, 2002.

Le Truet, H., Forchon, M., Boucher, O., and Li, X.-Z.: Sulfate aerosol indirect effect and $\mathrm{CO}_{2}$ greenhouse forcing: equilibrium response of the LMD GCM and associated cloud feedbacks, J. Climate, 11, 1673-1684, 1998.

Meador, W. E and Weaver, W. R.: Two-stream approximation to radiative transfer in planetary atmospheres: a unified description of existing methods and new improvement, J. Atmos. Sci., 37, 630-643, 1980.

Meloni, D., di Sarra, A., Di Iorio, T., and Fiocco, G.: Influence of the vertical profile of Saharan dust on the visible direct radiative forcing, J. Quant. Spectrosc. Ra., 93, 347-413, 2005.

Pace, G., di Sarra, A., Meloni, D., Piacentino, S., and Chamard, P.: Aerosol optical properties at Lampedusa (Central Mediterranean). 1. Influence of transport and identification of different aerosol types, Atmos. Chem. Phys., 6, 697-713, 2006, http://www.atmos-chem-phys.net/6/697/2006/.

Pace, G., Meloni, D., and di Sarra, A.: Forest fire aerosol over the Mediterranean basin durin summer 2003, J. Geophys. Res., 110, D21202, doi:1029/2005JD005986.

Paltridge, G. W. and Platt, C. M. R.: Radiative Processes in Meteorology and Climatology, Elsevier Publishing, 1976.

Ramanathan V., Crutzen, P. J., Lelieveld, J., Mitra, A. P., Althausen, D., Anderson, J., Andreae, M. O., Cantrell, W., Cass, G. R., Chung, C. E., Clarke, A. D., Coakley, J. A., Collins, W. D., Conant, W. C., Dulac, F., Heintzenberg, J., Heymsfield, A. J., Holben, B., Howell, S., Hudson, J., Jayaraman, A., Kiehl, J. T., Krishnamurti, T. N., Lubin, D., McFarquhar, G., Novakov, T., Ogren, J. A., Podgorny, I. A., . Prather, K, Priestley, K., Prospero, J. M., Quinn, P. K., Rajeev, K., Rasch, P., Rupert, S., Sadourny, R., Satheesh, S. K., Shaw, G. E., Sheridan, P., and Valero, F. P. J.: Indian Ocean Experiment: an integrated analysis of the climate forcing and effects of the great Indo-Asian haze, J. Geophys. Res., 106, 28 371-28 398, 2001.

Reddy, M. S., Boucher, O., Balanski, Y., and Schulz, M.: Aerosol optical depths and direct radiative perturbations by species and source type, Geophys. Res. Lett., 32, L12803, doi:10.1029/2004GL021743, 2005.

Rossow, W. B. and Schiffer, R. A.: Advances in understanding clouds from ISCCP, Bull. Amer. Meteor. Soc., 80 , 2261-2287, 1999.

Russell, P. B., Livingston, J. M., Hignett, P., Kinne, S., Wong, J., Chien, A., Bergstrom, R., Durkee, P., and Hobbs, P. V.: Aerosolinduced radiative flux changes off the United States mid-Atlantic coast: Comparison of values calculated from Sun photometer and in situ data with those measured by airborne pyranometer, J. Geophys. Res., 104, 2289-2307, 1999.

Santese, M., De Tomasi, F., and Perrone, M. R.: Advection patterns and aerosol optical and microphysical properties by AERONET over south-east Italy in the central Mediterranean, Atmos. Chem. Phys., 8, 1881-1896, 2008,

http://www.atmos-chem-phys.net/8/1881/2008/.
Schaaf, C. B., Gao, F., Strahler, A. H., Lucht, W., Li, X., Tsang, T, Strugnell, N. C., Zhang, X., Jin, Y., Muller, J.-P., Lewis, P, Barnsley, M., Hobson, P., Disney, M., Roberts, G., Dunderdale, M., Doll, C., d'Entremont, R. P., Hu, B., Liang, S., Privette, J., L., and Roy, D.: First operational BRDF, albedo nadir reflectance products from MODIS, Remote Sens. Environ., 83, 135-148, 2002.

Schulz, M., Textor, C., Kinne, S., Balkanski, Y., Bauer, S., Berntsen, T., Berglen, T., Boucher, O., Dentener, F., Guibert, S., Isaksen, I. S. A., Iversen, T., Koch, D., Kirkevåg, A., Liu, X., Montanaro, V., Myhre, G., Penner, J. E., Pitari, G., Reddy, S., Seland, Ø., Stier, P., and Takemura, T.: Radiative forcing by aerosols as derived from the AeroCom present-day and pre-industrial simulations, Atmos. Chem. Phys., 6, 5225-5246, 2006 , http://www.atmos-chem-phys.net/6/5225/2006/.

Stier, P., Feichter, J., Kinne, S., Kloster, S., Vignati, E., Wilson, J., Ganzeveld, L., Tegen, I., Werner, M., Balkanski, Y., Schulz, M., Boucher, O., Minikin, A., and Petzold, A.: The aerosolclimate model ECHAM5-HAM, Atmos. Chem. Phys., 5, 11251156, 2005, http://www.atmos-chem-phys.net/5/1125/2005/.

Stier, P., Seinfeld, J. H., Kinne, S., and Boucher, O.: Aerosol absorption and radiative forcing, Atmos. Chem. Phys., 7, 52375261, 2007,

http://www.atmos-chem-phys.net/7/5237/2007/.

Tafuro, A. M., Barnaba, F., De Tomasi, F., Perrone, M. R., and Gobbi, G. P.: Saharan dust particle properties over the Central Mediterranean, Atmos. Res., 81, 67-93, 2006.

Tafuro, A. M., Kinne, S., De Tomasi, F., and Perrone, M. R.: Annual cycle of aerosol direct radiative effect over southeast Italy and sensitivity studies, J. Geophys. Res., 112, D20202, doi:10.1029/2006JD008265, 2007.

Tafuro, A. M., De Tomasi, F., and Perrone, M. R.: Remote Sensing of Aerosols by Sunphotometers and Lidar Techniques, Chapter 14, in: Advanced Environmental Monitoring, edited by: Kim, Y. J., Platt, U., Springer, ISBN 978-1-4020-6363-3, XXII, 179-189, 2008.

Takemura, T., Nozawa, T., Emori, S., Nakajima, T. Y., and Nakajima, T.: Simulation of climate response to aerosol direct and indirect effects with aerosol transport-radiation model, J. Geophys. Res.-Atmos., 110, D02202, doi:10.1029/2004JD005029, 2005.

Yu, H., Kaufman, Y. J., Chin, M., Feingold, G., Remer, L. A., Anderson, T. L., Balkanski, Y., Bellouin, N., Boucher, O., Christopher, S., DeCola, P., Kahn, R., Koch, D., Loeb, N., Reddy, M. S., Schulz, M., Takemura, T., and Zhou, M.: A review of measurement-based assessments of the aerosol direct radiative effect and forcing, Atmos. Chem. Phys., 6, 613-666, 2006, http://www.atmos-chem-phys.net/6/613/2006/.

Zhou, Mi, Yu, H., Dickinson, R.E., Dubovik, O., and Holben, B. N.: A normalized description of the direct effect of key aerosol types on solar radiation as estimated from Aerosol Robotic Network aerosols and Moderate Resolution Imagining Spectroradiometer albedos, J. Geophys. Res., 110, D19202, doi:10.1029/2005JD005909, 2005. 